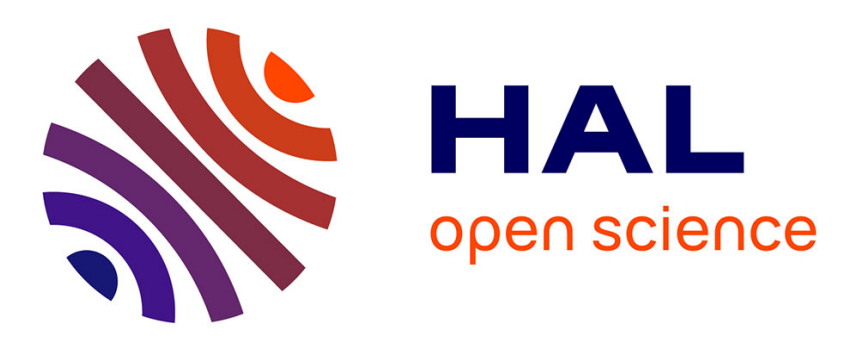

\title{
Inversion tectonics during continetal rifting: The Turkana Cenozoic rifted zone, northern Kenya
}

\author{
B. Le Gall, W. Vétel
}

\section{To cite this version:}

B. Le Gall, W. Vétel. Inversion tectonics during continetal rifting: The Turkana Cenozoic rifted zone, northern Kenya. Tectonics, 2005, 24, pp.TC2002. 10.1029/2004TC001637 . hal-00112696

\section{HAL Id: hal-00112696 \\ https://hal.science/hal-00112696}

Submitted on 15 Feb 2011

HAL is a multi-disciplinary open access archive for the deposit and dissemination of scientific research documents, whether they are published or not. The documents may come from teaching and research institutions in France or abroad, or from public or private research centers.
L'archive ouverte pluridisciplinaire HAL, est destinée au dépôt et à la diffusion de documents scientifiques de niveau recherche, publiés ou non, émanant des établissements d'enseignement et de recherche français ou étrangers, des laboratoires publics ou privés. 


\title{
Inversion tectonics during continental rifting: The Turkana Cenozoic rifted zone, northern Kenya
}

\author{
B. Le Gall and W. Vétel \\ UMR 6538 "Domaines Océaniques," Institut Universitaire Européen de la Mer/CNRS-UBO, Plouzané, France \\ C. K. Morley \\ Department of Petroleum Geoscience, Universiti Brunei Darussalam, Brunei
}

Received 3 September 2004; revised 29 November 2004; accepted 13 December 2004; published 5 March 2005.

[1] Remote sensing data and revised seismic reflection profiles provide new insights about the origin of inverted deformation within Miocene-Recent basins of the Turkana rift (northern Kenya) in the eastern branch of the East African rift system. Contractional structures are dominated by weakly inverted sets of fault blocks within $<3.7$ Myr old synrift series. Most of reverse extensional faults involve components of oblique-slip, whereas associated hanging wall folds are characterized by large wavelength upright folding. The area of basin inversion is restricted to a $40 \times 100 \mathrm{~km}$ elongated zone overlying a first-order $\mathrm{N} 140^{\circ} \mathrm{E}$ trending fault zone in the basement, referred to as the N'Doto transverse fault zone (NTFZ). In the proposed kinematic model, inversion tectonics is assigned to permutation of principal stress axes $\left(\sigma_{1} / \sigma_{2}\right)$ in addition to the clockwise rotation of extension (from nearly $\mathrm{N} 90^{\circ} \mathrm{E}$ to $\mathrm{N} 130^{\circ} \mathrm{E}$ ) during Pliocene. The transition from pure extension (Miocene) to a wrench faulting regime (Pliocene) first results in the development of T-type fault networks within a dextrally reactivated shear zone (NTFZ). Inversion tectonics occurred later $(<3.7 \mathrm{Ma})$ in response to a still rotated $\left(\sim 20^{\circ}\right)$ shortening axis $\left(\sigma_{1}\right)$ oriented $\mathrm{N} 40^{\circ} \mathrm{E}$ that caused the oblique compression of earlier (NS to $\mathrm{N} 20^{\circ} \mathrm{E}$ ) extensional structures within the NTFZ. The origin of basin inversion and strain concentration in the Turkana rift is thus directly linked to a crustal weakness zone, transverse to the rift axis, and involving steep prerift anisotropies. Citation: Le Gall, B., W. Vétel, and C. K. Morley (2005), Inversion tectonics during continental rifting: The Turkana Cenozoic rifted zone, northern Kenya, Tectonics, 24, TC2002, doi:10.1029/2004TC001637.

\section{Introduction}

[2] This paper deals with aspects of positive inversion in intracontinental rift setting. The term "inversion" is used to

Copyright 2005 by the American Geophysical Union. 0278-7407/05/2004TC001637\$12.00 describe regions which have experienced a reversal from subsidence to uplift [Harding, 1983; Gillcrist et al., 1987] during the contractional reactivation of previously extensional faults and basins [Hill and Cooper, 1996]. Inversion tectonics is a common feature of many mature sedimentary basins formed on continental crust, prior or after oceanic spreading [Ziegler, 1988]. Well developed examples of basin inversion occur along the northeast Atlantic margins of Norway and Britain, and their origin has been variously interpreted as a response to either local stress induced by shearing [Brekke and Riis, 1987], or far-field stress in relation to Alpine compression [Ziegler, 1989; Doré et al., 1999], oceanic ridge-push [Price et al., 1997], or oceanic transform motion [Doré and Lundin, 1996]. Inversion tectonics occurs also quite widely in continental rifts, and areas of inversion in the reference Cenozoic East African rift system (EARS in the text) are reported to the Afar [Arthaud et al., 1980; Gaulier and Huchon, 1991], and Rukwa sectors [Ring, 1994; Morley et al., 1992], as well as to the Turkana area [Morley et al., 1999a] which is the subject of the present work (Figure 1a). The various kinematic models so far proposed for inverted basins in the EARS imply disturbances of the stress field in relation with transform fault in the Afar rift [Arthaud et al., 1980], plate-scale mechanisms in the Turkana rift [Morley et al., 1999a], and permutation and/or rotation of stress axes in the Rukwa rift [Ring et al., 1992]. According to Morley et al. [1999a], the Turkana inverted rift basins (northern Kenya) are the consequence of either external or more local lithospheric-scale processes linked with, respectively, the Red Sea-Gulf of Aden spreading centers, and thermomechanical processes occurring under the Turkana rift itself (magmatic underplating, reduction of buoyancy forces, etc.). However, the short duration and frequency of inversion process $(<3.7 \mathrm{Ma})$ in the Turkana rift are difficult to reconcile with the long-term stress conditions caused by the inferred platescale driving forces [Morley et al., 1999a]. Conversely, newly acquired structural data showing the restricted spatial distribution of inverted structures favor local-scale contractional mechanism as the main contributing factor for rift basin inversion in the Turkana extensional province. Some implications of our model deal with the importance of strike-slip versus extensional deformation during the latest rifting stage, whereas the role of preexisting oblique discontinuities on the overall architecture of the rifted zone is also discussed. Because of the young age $(<3.7 \mathrm{Ma})$ of 

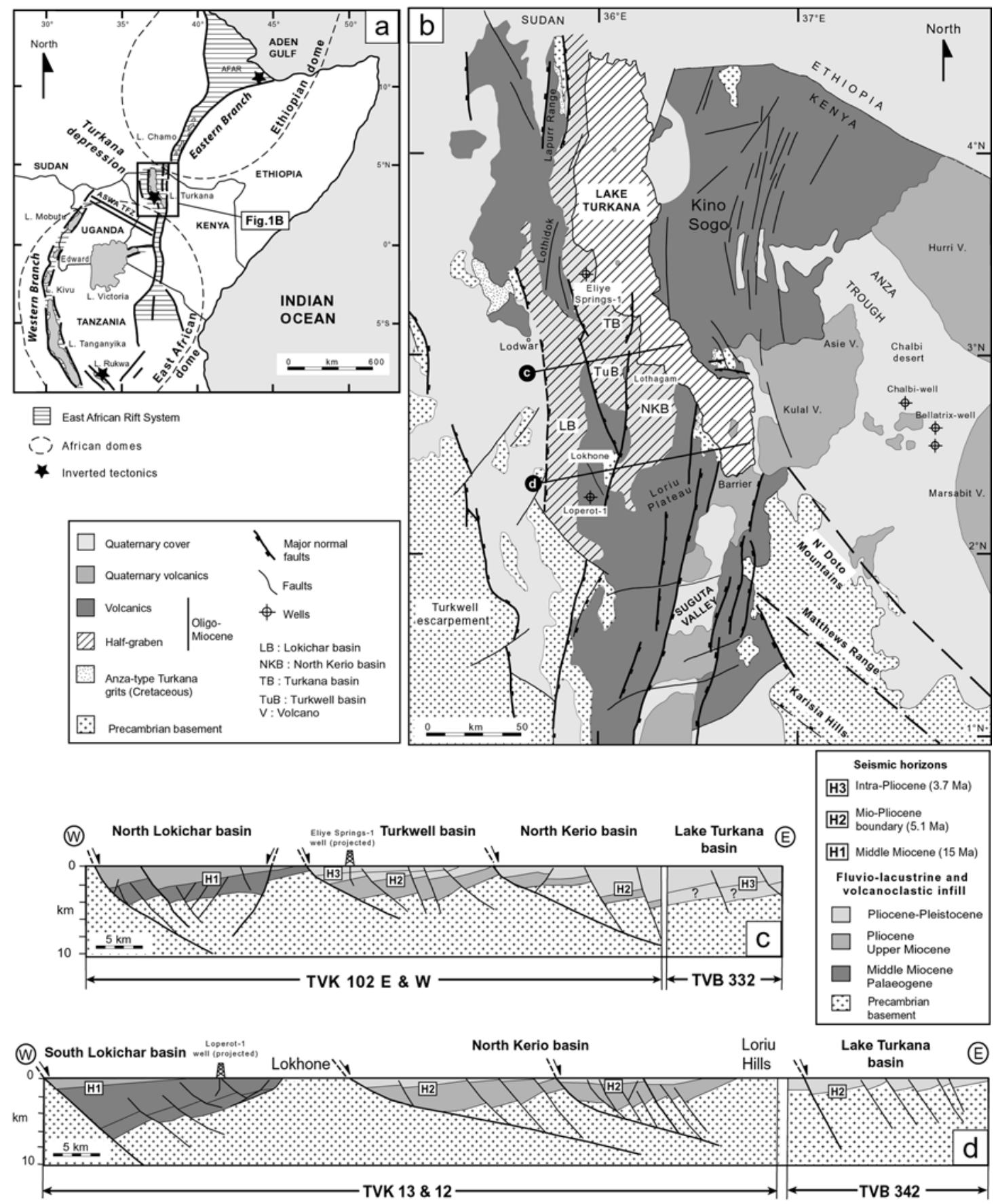

Figure 1. Tectonic framework of the Turkana Cenozoic Rift, northern Kenya. (a) Location of the Turkana rift in a large-scale Turkana transverse depression between the Ethiopian and Kenyan (plumerelated) domes. (b) Outline geological map of the Turkana Rift in Kenya. (c and d) Representative geological sections across the Turkana synrift basins network from seismic reflection data (Amoco TVK profiles and Probe TVB profiles) discussed in the text, modified from Morley et al. [1999b]. See location of the sections in Figure 1b. Note (1) the dominantly half-graben style (facing to the east) of the basins and (2) their progressive younging eastward and northward.

inverted structures, our study encompasses the time interval 5 Ma-Present, in contrast with most of previous works that concentrated on Oligocene-Miocene structures typically formed during the onset of extension and basin develop- ment in northern Kenya. In addition to (partly revised) conventional seismic reflection profiles previously interpreted by Dunkelman et al. [1989] for the offshore basins (PROBE TVB profiles of Lake Turkana), and Morley et al. 
[1992, 1999b] for the onshore basins (AMOCO TVK profiles), our work integrates satellite imagery (Landsat Thematic Mapper, $\times 4$ ) in order to correlate surface geology with seismically imaged basinal structures.

\section{Regional Rift Setting}

[3] Within the EARS, the Turkana Cenozoic rifted zone lies in a pronounced $\mathrm{N} 140^{\circ} \mathrm{E}$ trending oblique depression between the Ethiopian and East African domes (Figure 1a). In this area, the roughly NS striking Cenozoic rift structures are oblique to earlier NW-SE rift basins that developed during Cretaceous-Paleogene times in the Anza (SE) and south Sudan (NW) sectors [Schull, 1988; Bosworth and Morley, 1994]. From gravity data, these early rift systems are assumed to die out laterally toward Lake Turkana [Reeves et al., 1987; Dindi, 1994]. Alternatively, the Cretaceous basins may link via a putative EW transfer zone lying in southern Ethiopia, north of the present lake [Bosworth, 1992; Hendrie et al., 1994; Ebinger and Ibrahim, 1994].

[4] The Turkana rift forms a nearly 120-km-wide broad deformed zone that narrows progressively southward in central Kenya where the rifted zone attains a maximum width of $\sim 80 \mathrm{~km}$ across the Elgayo-Baringo transect. To the north, the Turkana rift gives way into the 300-km-wide complex system of basins and ranges within the broadly rifted zone of southwestern Ethiopia [Ebinger et al., 2000].

[5] Following acquisition of seismic reflection profiles in the late 1980s and early 1990s, the subsurface data of the Turkana area was further calibrated by two boreholes in the Loperot $(2950 \mathrm{~m})$ and Eliye Springs $(2964 \mathrm{~m})$ areas (Figure 1b). The Turkana Cenozoic rifted zone is known to form a $200 \times 100 \mathrm{~km}$ extensional province comprising a series of nearly NS trending half-grabens, arranged into three parallel basin belts as far east as the eastern shore of modern Lake Turkana [Morley et al., 1992] (Figures 1c and 1d). The structural organization of the recent basins occupying Lake Turkana was previously defined by offshore seismic reflection data [Dunkelman et al., 1989].

[6] East of Lake Turkana, a discrete Miocene faultcontrolled depocenter is also documented in the Chalbi desert from industrial reflection seismic profiles crossing the easternmost part of the Anza trough (Figure 1b). There, Miocene terrigenous synrift sequences, as thick as $800 \mathrm{~m}$ in the Bellatrix well (Figure 1b), unconformably overlie Cretaceous rifted series [Winn et al., 1993; Morley et al., 1999c].

[7] Cretaceous and younger fault-bounded basins have not yet been observed beneath the Miocene and Quaternary volcanic complexes of the Kino Sogo plateau and the Suguta valley (Figure 1b). These regions are deformed by a dense recent/active grid fault network trending at $\mathrm{N} 10^{\circ} \mathrm{E}$ [Mohr and Wood, 1976; Bosworth and Maurin, 1993; W. Vétel et al., Geometry and growth of an inner rift fault pattern: The Kino Sogo Fault Belt, Turkana Rift (north Kenya), submitted to Journal of Structural Geology, 2004]. The large-scale geometry of the Turkana rift basins is illustrated on the structural dip sections of Figures 1c and 1d from onshore TVK seismic lines [Morley et al., 1999b], and a number of offshore TVB profiles [Dunkelman et al., 1989], further calibrated by the Loperot and Eliye Springs deep boreholes (Figure 1b). Three regional stratigraphic horizons are identified from bottom upward as $\mathrm{H}_{1}$ ( $15 \mathrm{Ma}), \mathrm{H}_{2}(5.1 \mathrm{Ma})$ and $\mathrm{H}_{3}(3.7 \mathrm{Ma})$ [National Oil Corporation of Kenya, 1992]. The high-amplitude horizon $\mathrm{H}_{2}$ marks a regionally distributed volcanic event [Haileab et al., 2004], almost constantly present on the whole seismic data set, and previously reported in the Lake Turkana basins as the "Turkana Reflector" [Dunkelman et al., 1989]. The 3.7 Myr old horizon is a volcanoclastic episode with a more localized distribution. The age of the youngest overlying series is not well calibrated, hence preventing any precise upper limit for timing of inversion tectonics in the Turkana basins.

[8] The Lokichar $(\sim 70 \times 20 \mathrm{~km})$, north Kerio, Turkwell and Turkana $(\sim 25 \times 50 \mathrm{~km}$ each $)$ onshore basins define a relatively intricate extensional system to the west. Its overall structure partly results from multiple pulses of deformation, accompanied by reversal in half-graben asymmetry, switch of half-graben polarities along strike, and lateral shift of strain with time eastward toward modern Lake Turkana (see Morley et al. [1992] and Morley [1999] for further details). Very few intrabasinal faults exist within the Lochichar east facing half-graben if compared to the north Kerio, Turkwell and Turkana basins. Its southwestern part contains the oldest $\left(\right.$ ante- $\left.\mathrm{H}_{1}\right)$ and thickest synrift deposits in the Turkana sector. They form a westerly thickening wedge of Paleogene to middle Miocene fluviolacustrine sediments, capped by a 300-m-thick basaltic sequence dated from 12.5 to $10.7 \mathrm{Ma}$ [Morley et al., 1992]. The maximum infill thickness (6$7 \mathrm{~km}$ ) occurs in the immediate hanging wall of the Lokichar easterly dipping master fault [Morley et al., 1992, 1999b] (Figures 1c and 1d).

[9] Further east, the north Kerio and Turkwell basins form two easterly facing half-grabens, Miocene-Pliocene in age, where younger synrift deposits (post- $\mathrm{H}_{2-3}$ ) are still preserved on top of a 4-km-thick (maximum) volcanoclastic package [Dunkelman et al., 1989]. They pass laterally northward into the Turkana and Lake Turkana basins that conversely display a prominent westerly polarity. Dunkelman et al. [1989] interpreted the rift basins in Lake Turkana in terms of the Tanganyika and Malawi styles of alternating half-grabens separated by oblique accommodation zones [Rosendahl, 1987; Spetch and Rosendahl, 1989]. These basins are not all confirmed in the present work, and, for ease of discussion, the Lake Turkana is basically subdivided into three major basins comprising the south and north basins, oriented at NS and linked by the intermediate central basin lying with a $\mathrm{N} 140^{\circ} \mathrm{E}$ oblique direction. The youngest stratigraphy $(<5.1 \mathrm{Ma})$ of the northern basins is directly tied by the Eliye Springs borehole (Figure 1c), whereas the presence of early Miocene sequences in the deepest part of the basin is not yet proved [Hendrie et al., 1994].

[10] The total extension recorded by the Turkana rifted zone since Miocene times is estimated to $30-40 \mathrm{~km}$ by Hendrie et al. [1994] from geophysical evidence and modeling of "unseen" erosion due to footwall uplift. A 

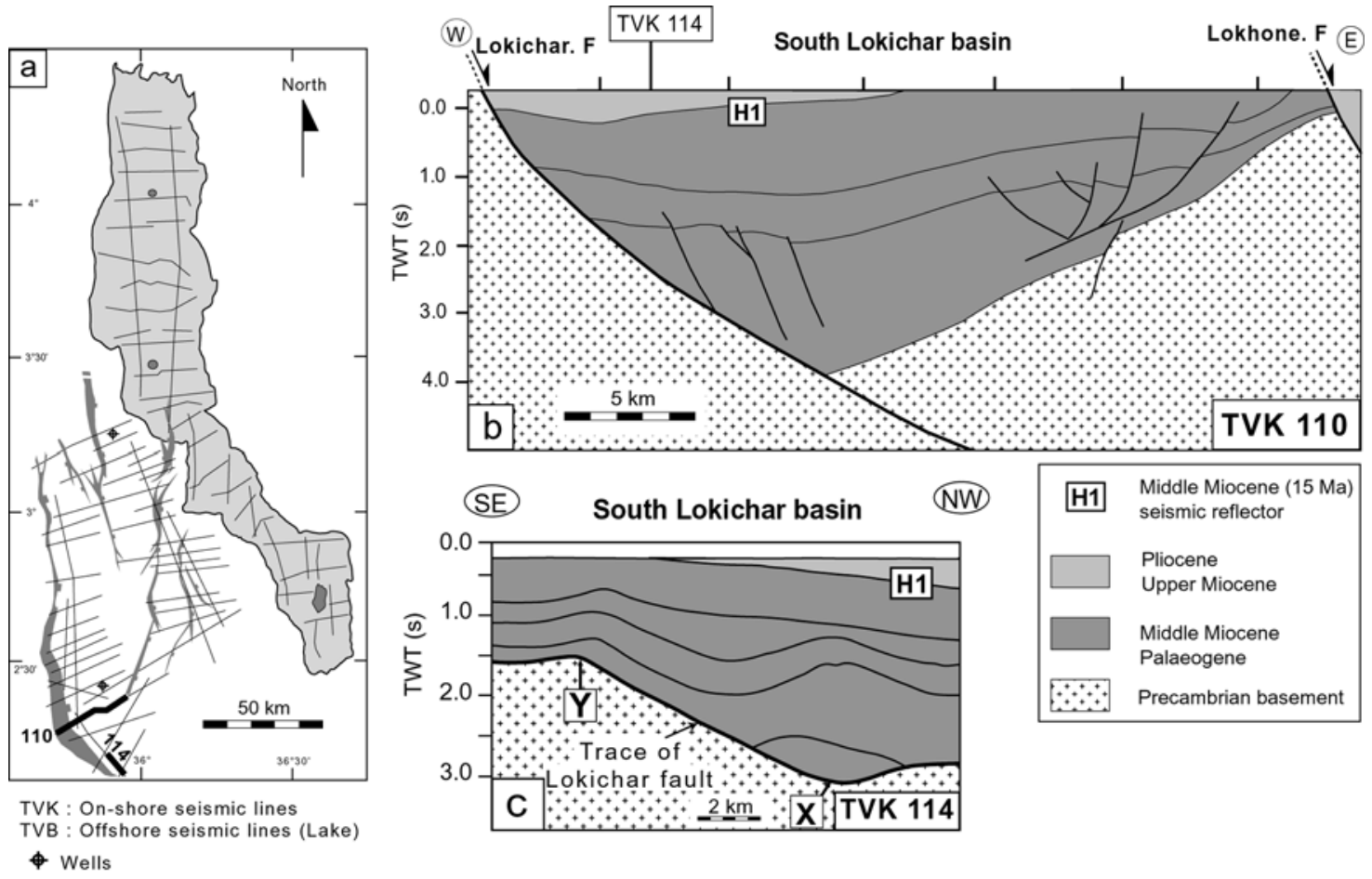

Figure 2. Example of extension-related fold-like structures (Type A) in the hanging wall of the Lokichar master fault. (a) Location map of onshore (TVK) and offshore (TVB) seismic lines recorded in the Turkana rift basins. The trace of the main rift bounding faults is also drawn, as well as the Eliye Springs and Loperot wells. (b) Sketch of structural cross section of the Lokichar half-graben showing the location of line TVK 114 in Figure 2c. (c) Kilometer-wavelength synform-antiform structures imaged on the strike section TVK 114 in Paleogene-middle Miocene series forming the immediate hanging wall of the Lokichar fault.

lower amount of extension at $\sim 20-25 \mathrm{~km}$ is applied here from the geometry of the rifted basins drawn on the $80-\mathrm{km}$ long transect of Figure 1d, when using the "antithetic shear model, with $\alpha=30^{\circ}$ " of Gibbs [1984]. The amount of extension within the poorly imaged Lake Turkana basins is badly constrained.

\section{Hanging Wall Fold-Fault Structures}

[11] The synrift sedimentary sections of the Turkana basins show a great number of fold/fault structures that resemble inverted features. From geometrical and kinematical indicators observed on interpreted seismic data, the folds appear to be of three origins. They are exhaustively listed below and referred to as "Type A, B, and C" structures. Since both Type A and Type B features are interpreted to have arisen as the consequence of extensional displacement along faults and emplacement of igneous intrusions, respectively, they are not reported in the main body of the text, which instead deals strictly with inversion structures (Type C) caused by large-scale contractional mechanisms.

\subsection{Extension-Related Fold Structures (Type A)}

[12] On the strike-line TVK 114 that cuts through the main depocenters of the Lokichar half-graben (Figure 2b), part of the lower Miocene synrift sequences lying in the hanging wall of the Lokichar master fault is involved into a pair of kilometer-wavelength upright folds with a vertical amplitude of nearly $0.5 \mathrm{~s}$ two-way travel time (TTWT) (approximately $800 \mathrm{~m}$ ) (Figure 2c). These folds occur within a synrift sedimentary section that thickens northward from 0.2 to $1.0 \mathrm{~s}$ (TTWT) above a step-like segment of the Lokichar fault [Boulet, 2003]. Since antiformal structures are not observed on the dip sections, they are likely to have formed during the extensional development of the Lokichar bounding fault in response to varying displacement along the fault plane. Similar mechanisms are applied by Morley et al. [1992] to local hanging wall deformations along the Lupa master fault in the Rukwa rift (Figure 1a).

[13] Above inflection point "Y," middle Miocene lacustrine series are involved in the anticline, whilst about $7 \mathrm{~km}$ further north, above inflection point "X," they clearly seal and postdate the folded strata. Folding in the Lokichar hanging wall strata is thus assumed to have developed diachronously as propagating southward.

[14] The anticline structures imaged on line TVK 114 are the only folded features so far documented in the Lokichar fault-bounded basin. Because of their inferred extensional origin in connection with the development of the Lokichar master fault, they are not indicative of 

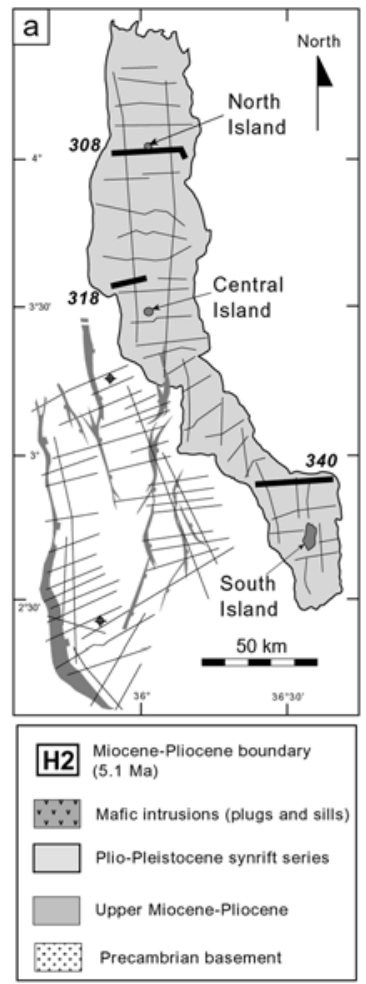

(1)
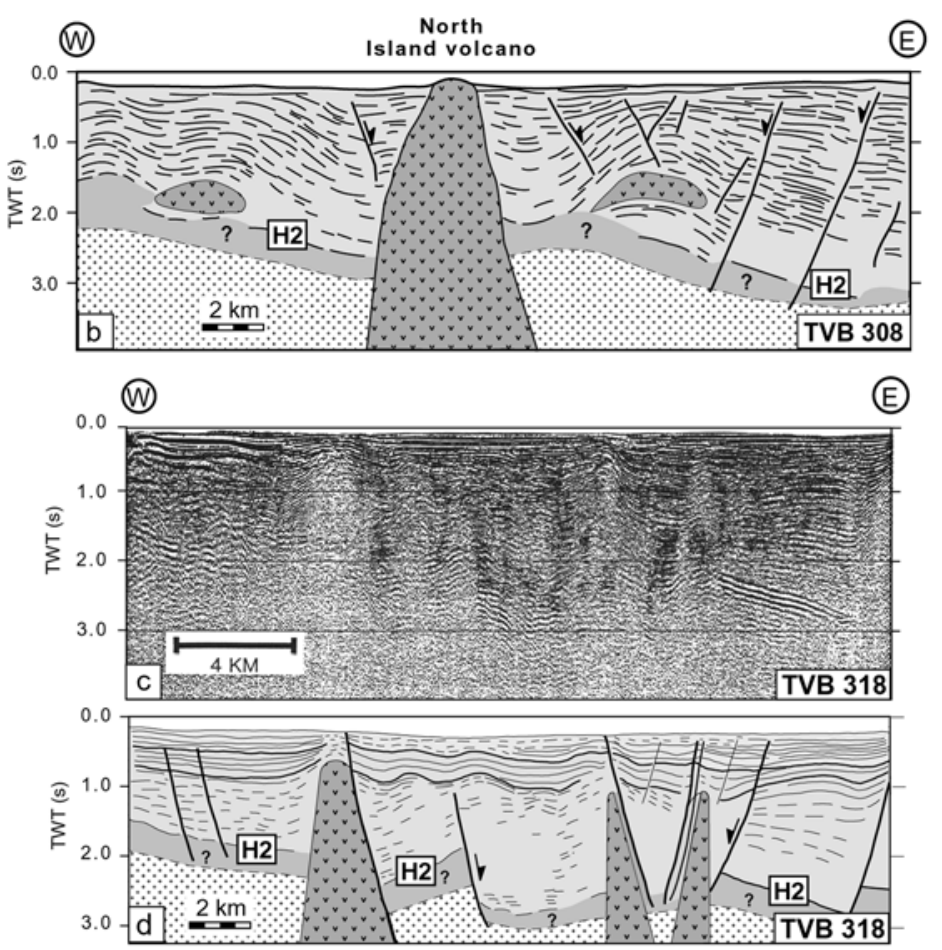

South Lake Turkana basin

(E)

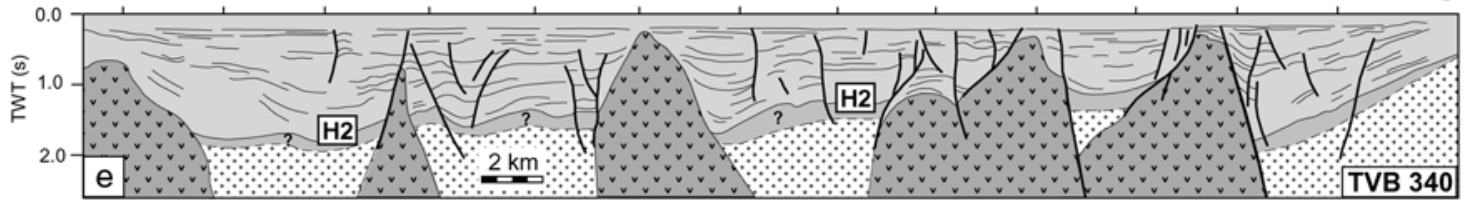

Figure 3. Evidence of intrusion-related fold structures (Type B) in Pliocene-Pleistocene sediments of Lake Turkana basins. (a) Similar location map as Figure 2a. (b) Structural interpretation of TVB 308 seismic reflection line (north basin). (c and d) Migrated and interpreted sections of TVB 318 seismic line (central basin). (e) Interpreted section of TVB 340 line (south basin). In the following, seismic data are illustrated by both raw and interpreted sections when concerning structures of interest and as a function of the quality of the available data. (Much of the data were made available to us only as variably degraded paper records.)

inversion tectonics, and as such are not considered in the following text.

\subsection{Igneous Intrusion-Induced Fold Structures (Type B)}

[15] A second type of folded structures is clearly imaged on a number of TVB seismic lines through the north (TVB 308), central (TVB 318), and south (TVB 340) basins of modern Lake Turkana (Figure 3).

[16] The best examples of folds are observed in the uppermost layered sequences $(<1 \mathrm{~s}$ TTWT $)$ overlying $\mathrm{H}_{2}$ horizon on the TVB 318 migrated section (Figure 3c). They express as upright and symmetrical antiforms, with a wavelength ranging from 1 to $0.5 \mathrm{~km}$. Most of them occur at the apex of steep seismically transparent bodies, typically $2 \mathrm{~km}$ wide. Similar chaotic seismic facies are visible on lines TVB 308 and TVB 340 as elliptic and horizontal bodies totally surrounded by sediments (Figures $3 \mathrm{~b}$ and $3 \mathrm{e}$ ). The vertical transparent body of section TVB 308 connects directly upward into the north island volcano (Figure 3b) and, by extrapolation, all of them are regarded as recent mafic intrusions (plugs and sills), dated at $<3.2 \mathrm{Ka}$ in the south island volcanics [Ferguson and Harbott, 1982].

[17] Emplacement of magmatic bodies within the middle/ upper crust is known to modify stress conditions and to build up temporary horizontal high-compressive stress [Rubin and Pollard, 1988], as exemplified along midoceanic ridges [Opheim and Gudmundsson, 1989; Villemin et al., 1994; Curewitz and Karson, 1998]. The deformed and highly fractured strata imaged along the walls of some shallow intrusions (Figures $3 \mathrm{~d}$ and $3 \mathrm{e}$ ) are thus likely to have been induced by both doming above underlying 
intrusions and buckling from temporary high horizontal compressive stress during forceful emplacement of magma. The abundance of intrusions and associated deformation increases markedly southward in the south basin (Figure 3e). There, the dense network of steep faults, with locally reverse displacement, that dissect the synrift sequences might result from the shortening necessary to accommodate magmatic intrusions which occupy $35 \%$ of the area of the complete dip section TVB 340 (Figure 3e). However, enhanced horizontal compressional stress resulting from magma pressure alone cannot account for the totality of inversion tectonics within the Turkana rift, since a number of fold/fault inverted structures occur within areas totally devoid of recent high-level intrusive centers. This last type of structures (Type C) is particularly abundant in the Turkana and north Kerio onshore basins, but a few of them also occur in parts of the Lake Turkana offshore basins.

\subsection{Inverted Structures (Type C)}

[18] As recognized in most of inverted basins [Ziegler, 1987; Coward, 1996], inversion tectonics in the Turkana rift is dominated by the reactivation of preexisting extensional fault networks. On the basis of the geometry and the inherited or newly formed origin of the reverse faults, as well as on the structure of the associated deformed strata, four main sorts of "Type C" fold/fault structures are distinguished below. They correspond for the most part to those described by Morley et al. [1999a]. The nature of the driving forces responsible for the Turkana inversion structures is then discussed from an integrated analysis of both seismic data set and onshore surface geology deduced from remote sensing imagery.

\subsubsection{Geometry of Inverted Structures}

[19] A first type of folded structure involves (upper?) Pliocene-Recent $(<5.1 \mathrm{Ma})$ sediments imaged on seismic dip lines across the central basin of Lake Turkana (Figure 4).

[20] The line TVB 330 (Figure 4b) shows kilometerwavelength and low-amplitude upright folds developed at the upper tip zones of steep faults ( $\mathrm{Fa}, \mathrm{Fb}$, and $\mathrm{Fc}$ in Figure 4c). The folded sequences form triangle-shaped wedges bounded or dissected by diverging small-scale faults that branch downward into the main fault (Figure 4c). Marked variations of post- $\mathrm{H}_{2}$ sediment thicknesses on both sides of faults $\mathrm{Fb}$ and Fc suggest that differential vertical movement took place along synsedimentary structures showing a NNW-SSE orientation on the post- $\mathrm{H}_{2}$ sediments isopach maps of Dunkelman et al. [1989]. The present-day slightly reverse attitude of faults $\mathrm{Fb}$ and $\mathrm{Fc}$ indicates some component of horizontal shortening $\left(\right.$ post- $\left.\mathrm{H}_{2}\right)$ parallel to the section (NE-SW). On the other hand, the fan-shaped branching fault network resembles flower-like structures typically formed in strike-slip fault regime [Harding, 1983; Sylvester, 1984]. Indeed, the fault diffraction geometry observed at the branching point of each diverging fault set, e.g., at a depth of about $1 \mathrm{~s}$ (TTWT), is close to the interface between highly reflective series (A) and a more transparent underlying sedimentary package (B) (Figure 4c). Hence the observed fault pattern resembles that commonly obtained in experimental modeling of strike-slip fault systems through litho- logically contrasted superposed sequences [Richard et al., 1995]. It is therefore suggested that the deformation recorded by the NNW-SSE trending faults $\mathrm{Fa}, \mathrm{Fb}$ and Fc during or after synsedimentary activity involves both shortening and strikeslip displacement.

[21] A nearly similar reactivated fault system is observed further north on seismic line TVB 326 (Figure 5b), close to the steep easterly dipping fault $(\mathrm{Fd})$ that represents an early extensional structure involving to the east a thick $\mathrm{H}_{2}-\mathrm{H}_{3}$ hanging wall sequence calibrated by the Eliye Springs well. Modest reversal of movement along $\mathrm{Fd}$ fault plane is indicated by the asymmetric and westerly verging large wavelength drag fold developed in its immediate hanging wall series. The gentle fold can be traced onto the adjacent line TVB 328 (Figure 5c) and its inferred NS/N160 ${ }^{\circ} \mathrm{E}$ direction is thus likely to result from a nearly EW oriented shortening. As stated above for the inverted faults of section TVB 330, reactivation of fault Fd might also integrate some lateral slip, as expressed by minor antithetic faults splay branching on the eastern side of the fault that still shows a preserved extensional geometry.

[22] A second type of folded structure still results from reactivated extensional fault, but without any strong evidence for strike-slip motion. The best examples are illustrated on the onshore seismic line TVK 11 that supplies a complete structural section, $\sim 100 \mathrm{~km}$ long, of the north Kerio basin and the southern extremity of the Turkana basin (Figure 6). The oblique section of Figure $6 \mathrm{~d}$ lies at low angle $\left(\sim 20^{\circ}\right)$ to the NS axis of the basins, and it shows two main depocenters $\left(\mathrm{H}_{2}-\mathrm{H}_{3}\right.$ sequences $)$ in the hanging wall of the Lothagam (Lo.F) and Kerio (K.F) faults. The wedge-shaped Pliocene sequences in the hanging wall of the Lo.F are folded into a $\sim 5-\mathrm{km}$ wavelength anticline, and they seem to override to the NNW the thinner footwall sequences, in turn, moderately inclined (apparent dip of $\sim 15^{\circ}$ ) to the NNW. The dip line TVK 102 cuts at high angle the fault trace and thus supplies the exact 2D-geometry of the structures (Figure 6f). This reverse faulting pattern is confirmed by field observations along the exceptionally well-exposed Lo.F scarp where tilted footwall volcanics, 4.7 Myr old [Haileab et al., 2004], are cut by the steep east facing Lo.F plane (Figure $6 \mathrm{f})$. The highly plunging $\left(55^{\circ}\right.$ to the ESE) slickenside striations measured on the fault surface are indicative of reverse displacement to the WNW, with a minor lateral component (Figure 6g).

[23] Further SSE on the seismic line TVK 11, the K.F also appears to have been inverted, with footwall series that are furthermore gently folded in an upright anticline. In both cases, the deformed footwall sequences are sharply truncated by the present-day erosion level. Additional supportive evidence for contractional deformation in the central part of the north Kerio basin are supplied by a series of upright folding and associated diverging faults that preferentially involve pre- $\mathrm{H}_{2}$ sequences (Figures $6 \mathrm{~b}$ and $6 \mathrm{c}$ ).

[24] The overall hanging wall/footwall structures depicted on line TVK 11 can be thus regarded as the consequence of coeval uplift and shortening processes developed in the vicinity of major rift faults. 

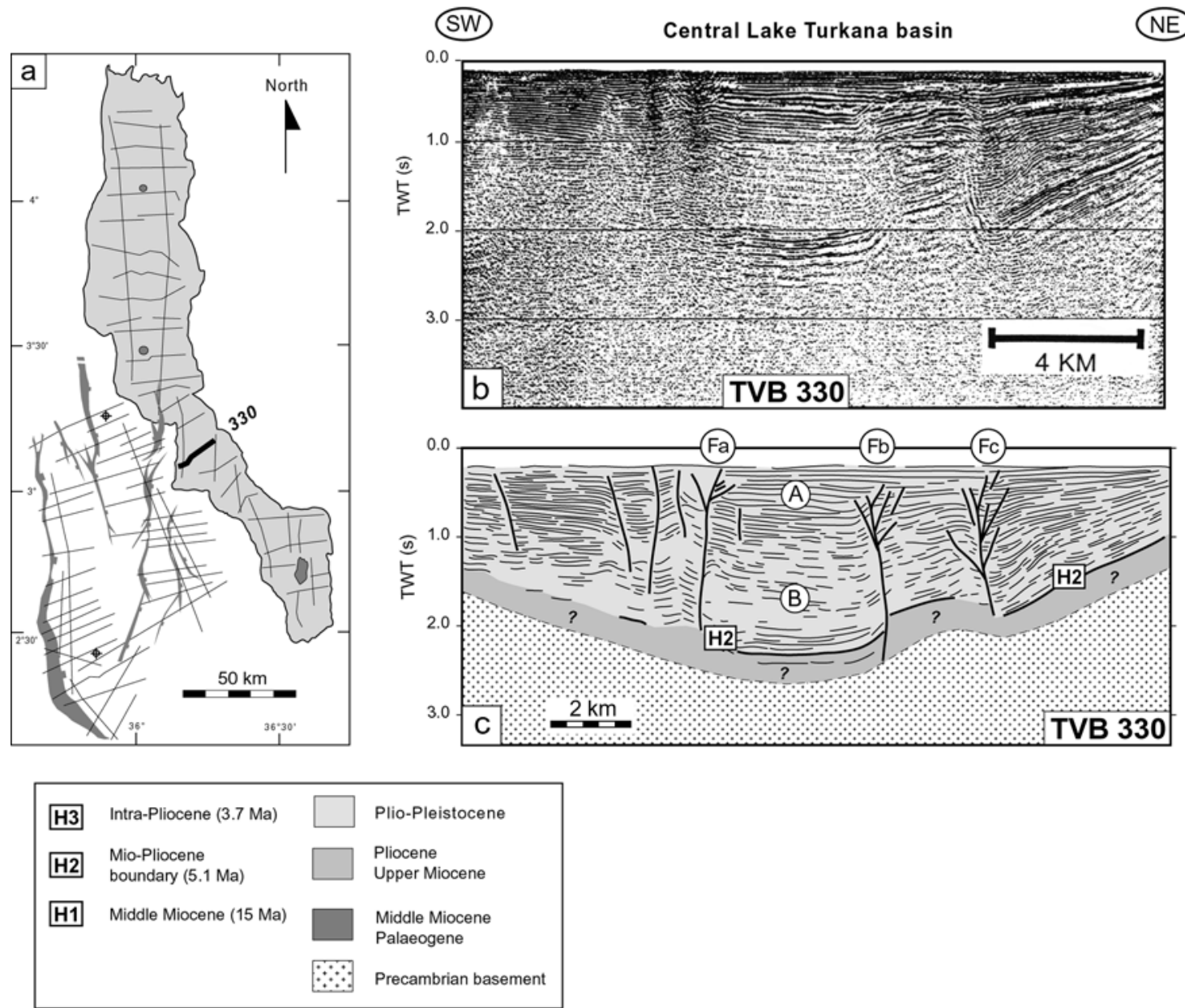

Figure 4. Strike-slip fault-induced deformation involving recent synrift series in the central basin of Lake Turkana. (a) Similar location map as Figure 2a. (b and c) Migrated and interpreted sections of line TVB 330 showing flower-like structures developed in sediments ( $<3.7 \mathrm{Ma})$ on top of steep faults (named $\mathrm{Fa}$ and $\mathrm{Fb}$ ). These faults, inferred to strike at $\sim \mathrm{N} 140^{\circ} \mathrm{E}$, show an extensional displacement at depth close to horizon $\mathrm{H}_{2}$. Letters refer to structures (faults and sedimentary packages) cited in the text.

[25] 3. A third type of inverted structures corresponds to newly formed low-angle reverse faults in the Pliocene series of the Turkana and north Kerio onshore basins [Morley et al., 1999a]. Their geometry in the southernmost part of the Turkana basin is depicted on the seismic sections in Figures $7 \mathrm{~b}$ and $7 \mathrm{c}$. The Pliocene-(Miocene?) sequences define an asymmetrical graben deepening to the east as the result of greater displacement along the westerly dipping Turkwell border fault network to the east. On line TVK 3 , across the median part of the basin, a shallowly dipping reverse fault cuts through the basement top and dies rapidly upward to the west within the sedimentary section (Figure 7b). The amount of throw is estimated at $0.5 \mathrm{~km}$ from basement top offset. This lowangle reverse fault forms, together with a steeper inverted normal fault $(\mathrm{Fe})$, a triangle-shaped undeformed zone. This composite compressional fault system is absent on the seismic line TVK 141 , about $10 \mathrm{~km}$ further south
(Figure 5). With regards to the large-scale graben-like profile imaged on the line TVK 3 (Figure 7b), the lowangle reverse fault initiates close to the inflection point $\mathrm{Y}$ between a flat-lying and shallow segment of the basin floor to the west, and an easterly dipping portion, reaching a maximum depth of 2.5-3.0 s (TWT) to the east.

[26] Other low-angle reverse faults also exist in the easternmost part of the Turkana graben. On line TVK 138 (Figure 7c), a west verging imbricate contractional wedge occurs in the hanging wall of the Turkwell fault zone, suggesting that this latter acted as a buttress. The entire reverse fault network roots at shallow depth along an easterly dipping decollement close to the base Pliocene level. It seems that the overall inverted deformation in the Turkana asymmetric graben preferentially develops within the thickest part of the synrift sedimentary infill, in agreement with experimental modeling of graben inversion tectonics [Brun and Nalpas, 1996]. 

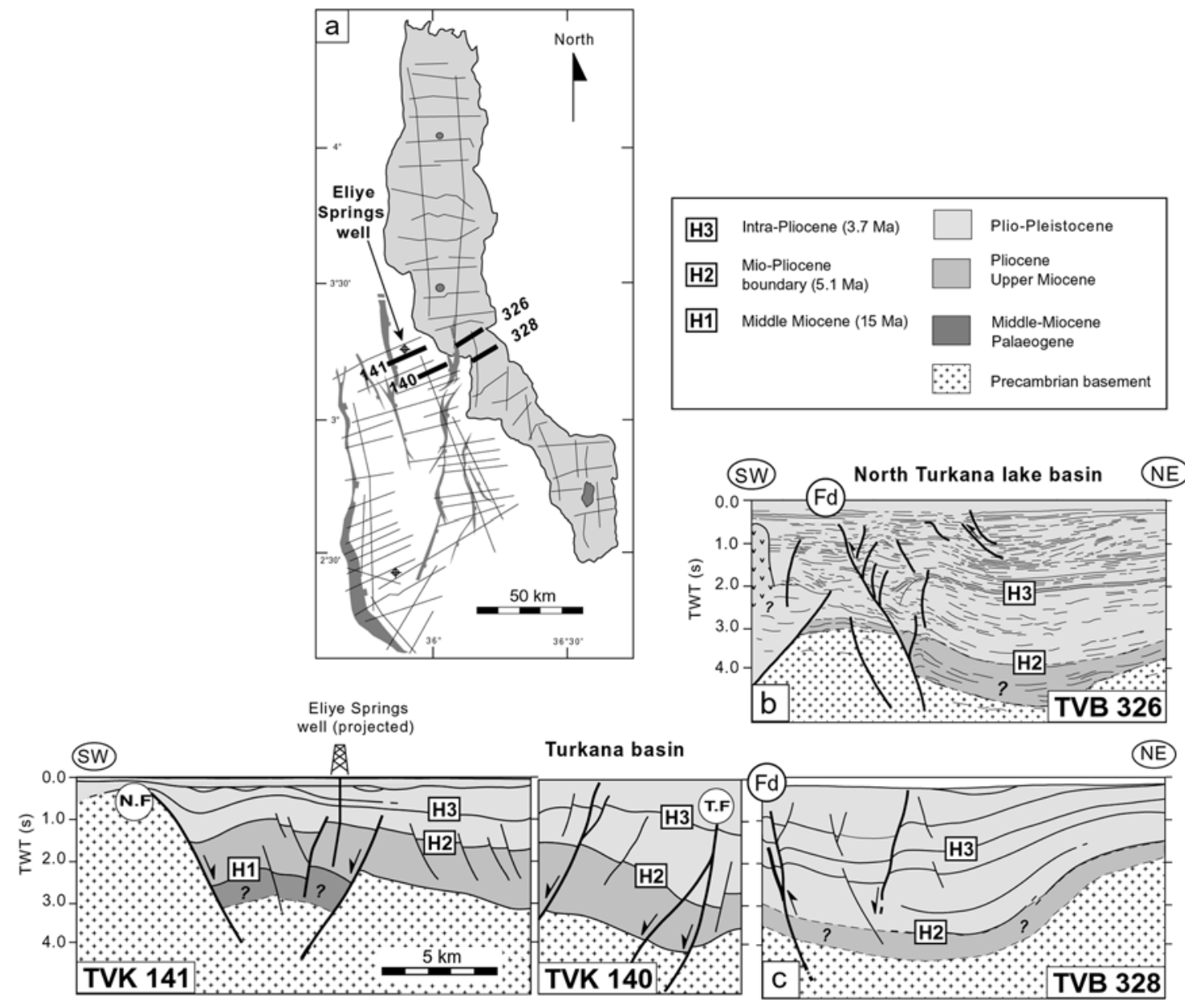

Figure 5. Slightly inverted basins in the Turkana rift resulting from reverse reactivation of earlier extensional faults. (a) Similar location map as Figure 2a. (b) Westerly verging drag folds in Pliocene sediments of the north basin (Lake Turkana) resulting from reversal of movement along an earlier extensional fault $(\mathrm{Fd})$. The minor fault splay branching along the uppermost part of fault Fd may indicate a slight component of oblique slip displacement. (c) Similar fold-fault geometry observed at the southern extremity of fault Fd on the calibrated seismic sections TVK 141, TVK 140, TVB 328. The infill stratigraphy of this composite line is tied with the Eliye Springs well (projected).

[27] 4. The last type of contractional features is imaged on the onshore seismic lines TVK 136-117-135-118-131 within the northernmost part of the north Kerio basin (Figure 8). Representative inverted deformations are imaged on the dip profile TVK 117 where shallow $(<1.5 \mathrm{~s}$ TTWT) Pliocene sediments [Morley et al., 1999a] are affected by a series of kilometer-wavelength upright anticlines, further disrupted by a closely spaced (1$2 \mathrm{~km}$ ) fanning fault network with locally reverse displacements. Contrasts in sediment thicknesses within adjacent fault-bounded blocks indicate that most of faults originated as extensional structures, prior to $\mathrm{H}_{3}$. A system of dominantly east facing tilted blocks $(\times 3)$, with minor antithetic westerly dipping faults, is recognized, and inversion tectonics appear to concentrate in the thickest depocenters to the east (X and $\mathrm{Y}$ on Figures $8 \mathrm{c}$ and $8 \mathrm{~d}$ ), in agreement with experimental models [Brun and Nalpas, 1996]. The combined reactiva- tion of diverging normal faults results in extrusive uplifted wedges which do not completely cancel the previous extensional fault offsets. According to Morley et al. [1999a] from geometrical estimates, the maximum amount of uplift on the depth-converted section of Figure $8 \mathrm{~d}$ is about $1 \mathrm{~km}$.

\subsubsection{Origin of the Turkana Inverted Structures 3.3.2.1. Spatial Distribution}

[28] Morley et al. [1999a] tried to explain the restriction of known inversion structures within the Kenya rift to only the Western Turkana region in terms of the interaction of local buoyancy forces with far-field stresses. Two key aspects of the inversion in Turkana basins which need to be explained by any putative mechanism are the short time span and the geographically restricted distribution of related structures. From calibrated seismostratigraphy, the onset of inversion tectonics in the Turkana rift basins is 

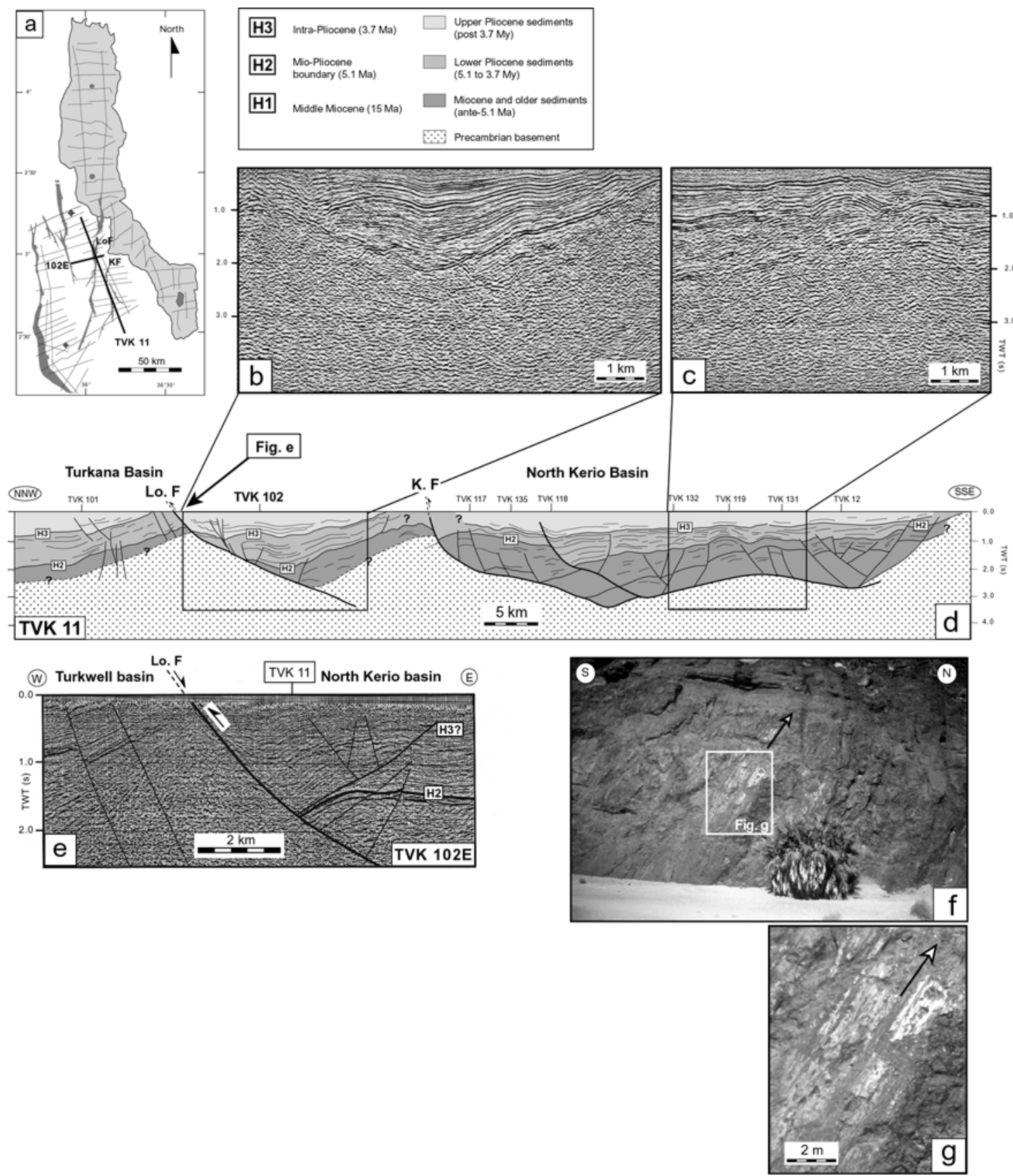

Figure 6. Contractional folding and reverse faulting in the Turkana and north Kerio onshore basins. (a) Similar location map as Figure 2a. (b and c) Focused view of the migrated seismic line TVK 11 showing folded synrift sequences (post-H3) in the hanging wall of the master fault Lo.F (Figure 6b) and a fault/fold linked system developed in the synrift series above the Kerio master fault (Figure 6c). (d) Structural interpretation of TVK 11 reflection seismic line cutting obliquely the Turkana and north Kerio basins. The two main distinct depocenters associated with the Lothagam and Kerio faults are clearly depicted. The inclined and eroded strata forming a monoclinal beneath the Lo.F may result from footwall uplift prior to or coeval with the reverse reactivation of Lo.F. (e) Interpreted seismic reflection line TVK 102E cutting at high angle the Lothagam fault system and illustrating upward arching of post-H2 synrift series [after Morley et al., 1999a]. (f) Field evidence for oblique sense of motion along the Lothagam master fault. Striations are plunging $50^{\circ}$ to the SSE. Black arrow indicates the attitude of the striaes of the fault surface. The palm tree is about $10 \mathrm{~m}$ high. (g) Focused view of striation on the Lothagam fault plane. 

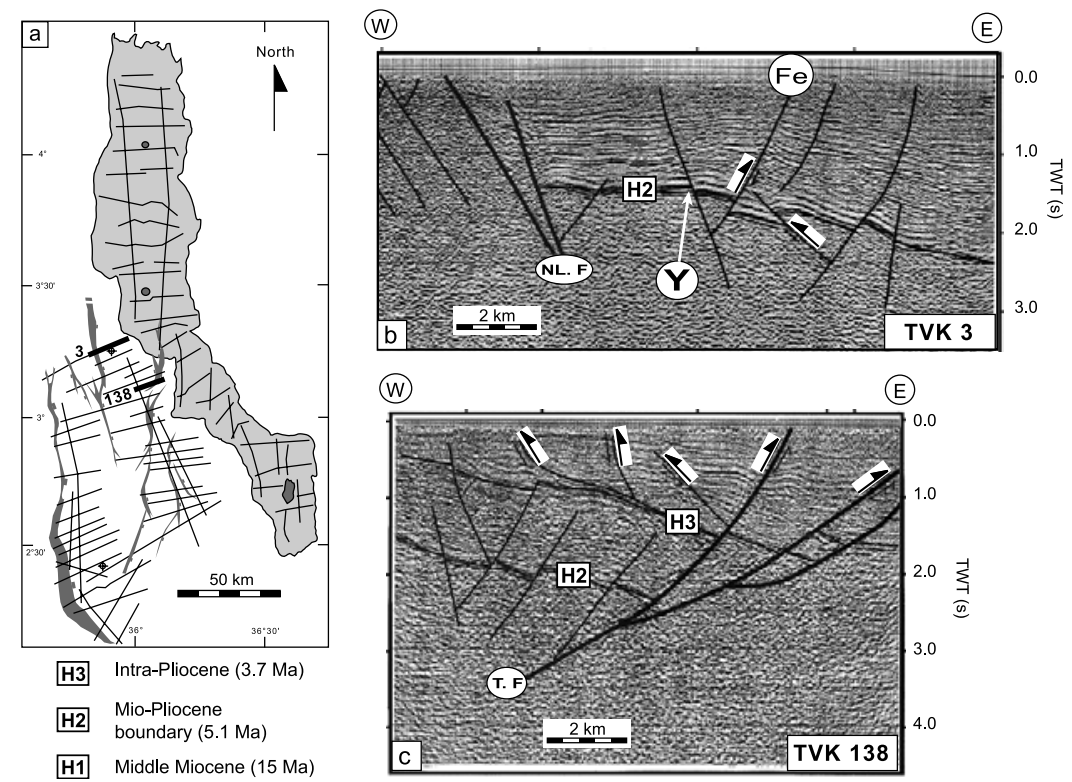

Figure 7. Examples of low-angle and newly formed reverse faults in Pliocene series of the Turkana onshore basin (see location in Figure 1b). (a) Similar location map as Figure 2a. (b) Steep (reactivated) and low-angle (newly formed) reverse faults in the Turkana asymmetric graben (line TVK 3). Note that inverted structures occur at depth close to basement top. NL.F, Napedet-Lothidok fault. (c) Similar reverse fault geometry in youngest series $\left(\right.$ post $\left.-\mathrm{H}_{3}\right)$ at the eastern faulted border of the Turkana basin. T.F, Turkwell fault.

assumed to have occurred during Upper Pliocene times, later than $3.7 \mathrm{Ma}$ (post- $\mathrm{H}_{3}$ ). Secondly, on the basis of the existing seismic grid, five discrete inverted zones are distinguished (Figure 9). Three main large areas extend as elliptic cartographic zones $(20 \times 40 \mathrm{~km})$ with a NS/ $\mathrm{N} 160^{\circ} \mathrm{E}$ trending axis at the northern extremity of the north Kerio basin and in its offshore prolongation. Two of them form the immediate hanging wall of the Lothagam and Kerio faults, onshore. Two smaller and round-shaped inverted areas also exist to the NW in the onshore Turkana basin. The absence of inverted deformations within the Lokichar half-graben to the west is noticeable. In map view, the overall inverted area is a $\sim 40 \times 100 \mathrm{~km}$ elongate zone, trending at $\mathrm{N} 160^{\circ} \mathrm{E}$, close to the oblique and central segment of modern Lake Turkana. It roughly coincides (except the central lake basin to the east) with a high-density zone of normal faulting, reported from seismic reflection data [Morley et al., 1999b] (Figure 9b), and shown as closely spaced and fan-verging reactivated structures on profile TVK 117 of Figure 8. With regards to the entire Turkana extensional fault network, the highdensity fault zone forms a $\sim 40$-km-wide transverse corridor at $\mathrm{N} 160^{\circ} \mathrm{E}$, in which fault traces swing markedly from a NS regional trend to a $\mathrm{N} 20^{\circ} \mathrm{E}$ oblique direction (Figure 9b).

[29] The overall linearity of the Turkana NS rift system is thus locally disturbed over a $\mathrm{N} 160^{\circ} \mathrm{E}$ elongate corridor, resulting firstly in the higher frequency and bifurcation of the previous extensional fault network, and secondly, in its reverse reactivation (Figure 9b). The spatial coinci- dence between inversion tectonics and anomalous extensional structures suggests a causal link between these two features. That leads us to precise the lateral extent and the origin of the anomalous fault zone from surface geological markers, and then to attempt to find timing and kinematic indicators for addressing its tectonic significance with respect to the long-lived evolution of the Turkana rift.

3.3.2.2. Evidence for Preexisting Oblique Discontinuities

[30] Interpretation of two Landsat TM images (169058, 23/10/1999 and 170-058, 18/01/2000) allows us to identify a number of structures that differ in nature and age along a regional-scale lineament lying over more than $300 \mathrm{~km}$ from the Lothidok plateau to the NW, to the southeastern edge of Lake Turkana, e.g., nearly along part of the above mentioned anomalous rift zone (Figure 10).

[31] 1. In the southern wedge-shaped segment of the Lothidok (Miocene) volcanic plateau, both fracture network and traces of tilted lava flows curve toward parallelism (from NS to $\mathrm{N} 160^{\circ} \mathrm{E}$ ) with the oblique fault-like limit bounding sharply the plateau to the SW (Figure 10a).

[32] 2. In the Loriu Hills, on the southwestern side of Lake Turkana, the trace of the Proterozoic foliation plane is dextrally deflected along a 15-km-long linear faulted zone, striking at $\sim \mathrm{N} 140^{\circ} \mathrm{E}$, parallel to the lake shoreline (Figure 10b). In the same area to the NW, the multistage rejuvenation of $\mathrm{N} 140^{\circ} \mathrm{E}$ striking fault/fractures is also inferred from a number of Tertiary dykes following a NW-SE trend, and from the southern faulted termination of Turkana Grits (Cretaceous or Miocene in age) exposures. 

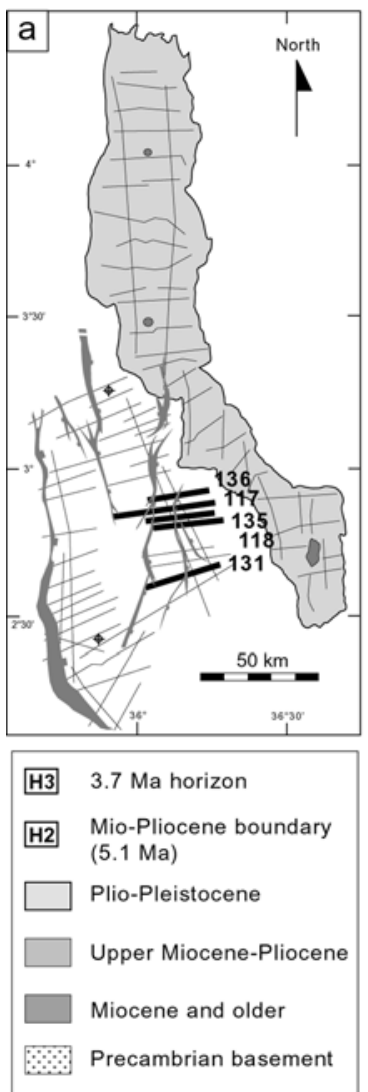
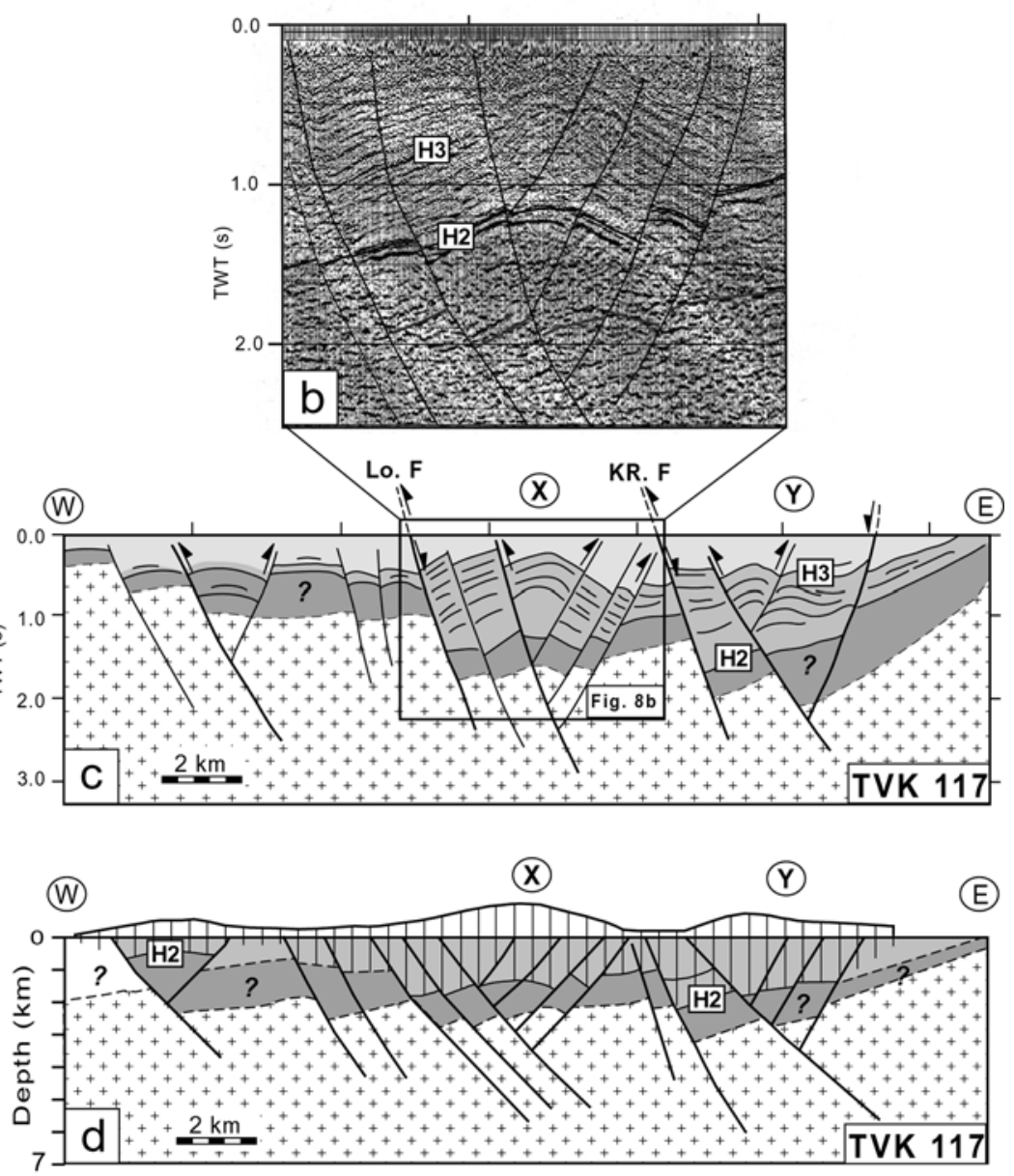

Figure 8. Upright folding and reverse faults in the north Kerio basin. (a) Similar location map as Figure 2a. (b) Portion of migrated seismic line TVK 117 across the small graben-like basin labeled " $X$ " on Figure 8c. A diverging fan of earlier normal faults displaying reversal of motion cuts inversion anticlines. (c) Interpreted seismic line TVK 117 showing the positive inversion of the deepest parts (labeled $\mathrm{X}$ and $\mathrm{Y}$ ) of the north Kerio basin. The localized distribution of the dense fault network is drawn on the map of Figure 9 (see text for discussion). (d) Depth-converted profile TVK 117 showing the amount of eroded section above the inverted zones, after Morley et al. [1999a].

[33] 3. In the Mount Porr area, on the opposite (eastern) side of Lake Turkana (Figure 10d), the E-W arrangement of Quaternary lacustrine sediments is disrupted by a set of $\mathrm{N} 140^{\circ} \mathrm{E}$ lineamentary fault-like structures that probably root at depth along Cenozoic faults bringing into contact Miocene volcanics and synrift sedimentary series (Turkana Grits) [Vétel et al., 2004].

[34] 4. At a greater scale, the Proterozoic basement terrains exposed on the eastern side of the central Kenya rift pass abruptly eastward into the Anza-Chalbi Plain along a NW-SE trending morphological scarp, laterally offset by oblique structures (Figure 10c). This topographical boundary is outlined to the east in the south Horr-N'Doto range by a narrow ( $\sim 20 \mathrm{~km}$ wide) strip of anomalously elevated relief (as high as $2000 \mathrm{~m}$ ) that suggests recent vertical movement. The location of this large-scale transverse faulted corridor, about $50 \mathrm{~km}$ east of the Suguta axial valley, excludes its origin from rift-flank uplift. It correlates on AMOCO seismic lines with the SW border fault system of the Anza rift and that indicates its nucleation at depth along Cretaceous structures that have been repeatedly rejuvenated in middle Miocene, as evidenced by apatite fission tracks thermochronology [Foster and Gleadow, 1992].

[35] From the line of structural evidence above, it is proposed that the Turkana Cenozoic rift comprises a large-scale basement-rooted discontinuity, referred to as the N'Doto transverse fault zone (NTFZ hereinafter), as long as $300 \mathrm{~km}$ and with a maximal width of nearly $40-$ $50 \mathrm{~km}$ over the E-W trending segment of modern Lake Turkana (Figure 10d). The NTFZ is part of a complex deep-seated fault network, involving also the so-called 


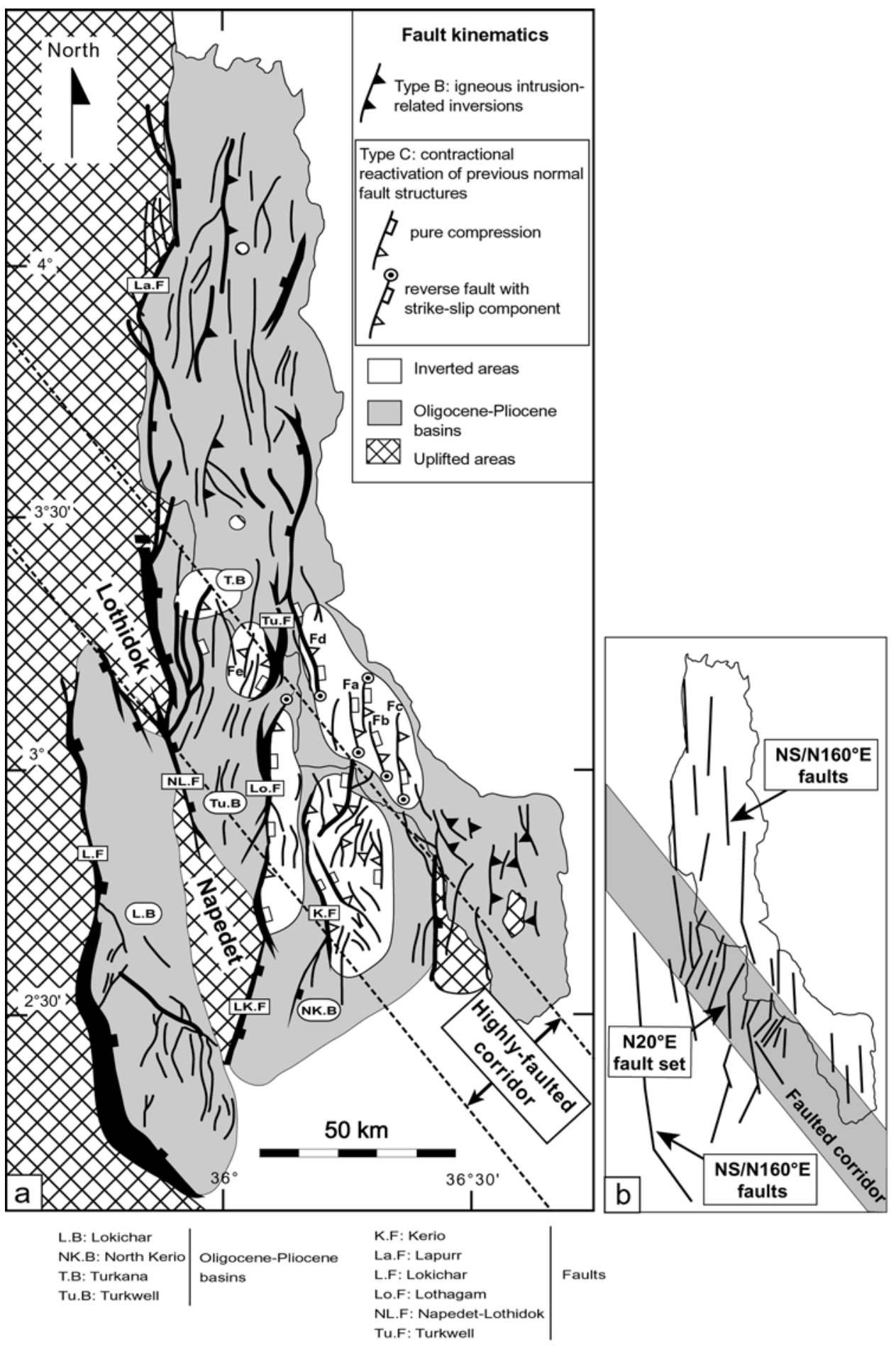

Figure 9. Map distribution of faults in the main onshore basins (Lokichar, north Kerio, Turkwell and Turkana) of the Turkana rift. (a) Restricted spatial location of inverted structures within discrete elongated areas occurring in a large-scale transverse corridor. This $40-\mathrm{km}$-wide structural corridor is also marked by a denser network of short and intrabasinal faults that swing at $\mathrm{N} 20^{\circ} \mathrm{E}$. Fa, Fb, Fc, and $\mathrm{Fd}$ refer to fault structures cited in the text. (b) Sketch of structural maps illustrating the change of fault direction within the $\mathrm{N} 140^{\circ} \mathrm{E}$ trending highly faulted corridor. 

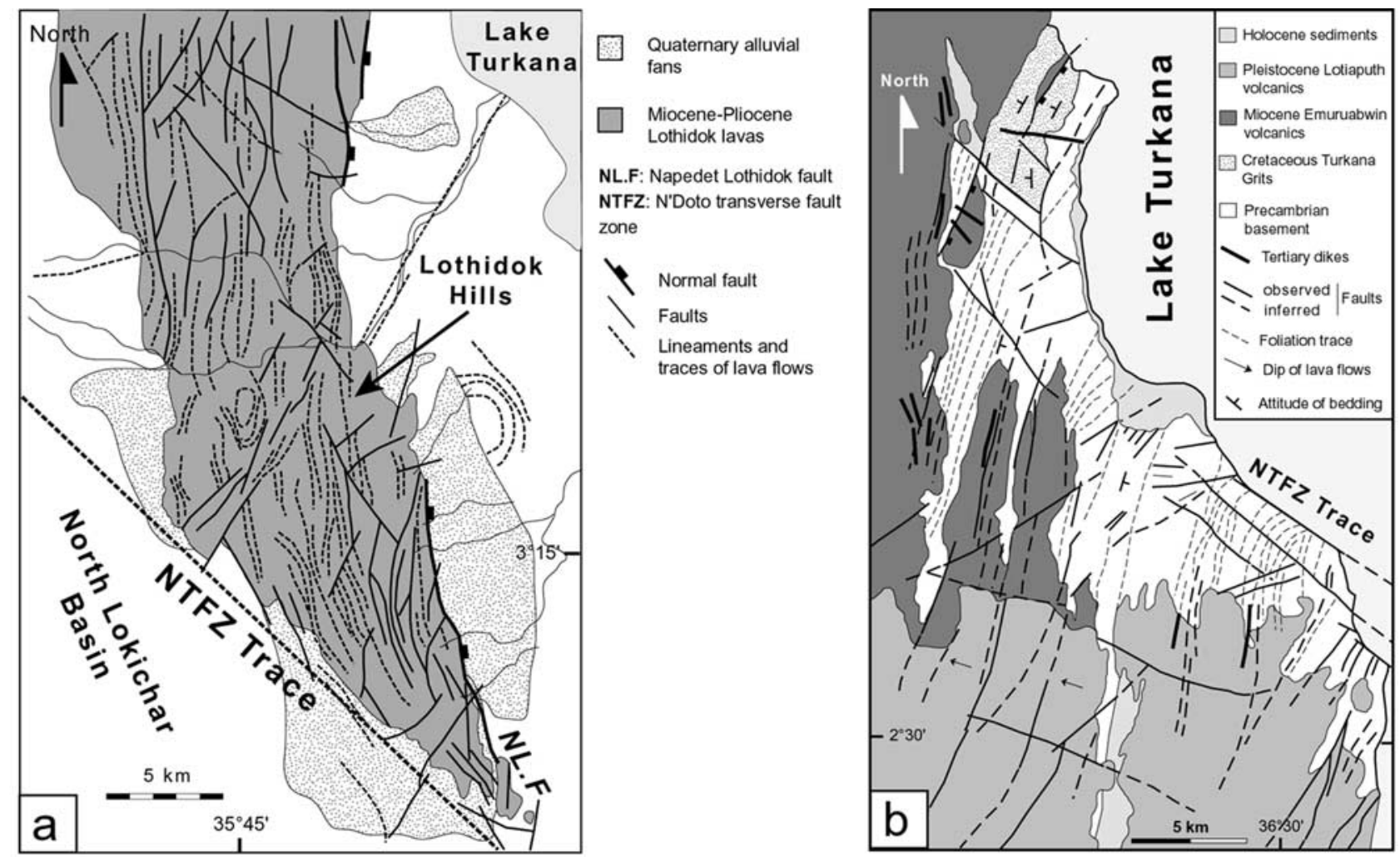

Figure 10. Evidence for a long-lived transverse $\left(\mathrm{N} 140^{\circ} \mathrm{E}\right)$ fault zone $\left(\mathrm{N}^{\prime}\right.$ Doto) in the Turkana Cenozoic rift. (a) Structural interpretation of the Landsat TM scene 169-058 in the southern extremity of the Lothidok Miocene volcanic plateau (see Figure 10d for location). The faulted origin of this boundary is evidenced by both the sharp southern termination of the volcanics and the cartographic virgation of both faults and lava flows. (b) Sketch map of the Loriu area (SW onshore side of Lake Turkana; see Figure 10d for location) from interpretation of the Landsat satellite scene TM 169-058. Note the oblique trend of the lakeshore and the cartographic inflection of basement foliation along a $\mathrm{N} 140^{\circ} \mathrm{E}$ (dextral?) fault inferred to be part of the NTFZ. (c) Detail view of SRTM (Shuttle Radar Topography Mission) digital elevation model (data from NASA) showing the transverse faulted boundary of the N'Doto basement relief, SE of Lake Turkana (see Figure 10d for location). The NTFZ is expressed by a 20-km-wide zone of highly fractured relief (with a maximum topographic elevation of $2000 \mathrm{~m}$ in the cross section X-Y drawn in Figure 10c). Within the $\mathrm{N} 140^{\circ} \mathrm{E}$ fault zone, fault block uplift occurs along NS trending structures following basement fabrics. (d) Synthetic structural map of the Turkana rift showing the distribution of inversion tectonics with regard to the first-order extensional and transverse fault networks identified in the present study from seismic and remote sensing data set. Same abbreviations as Figure 9a. The Kataboi and Buluk transverse fault zones (TFZ) are not discussed in the paper.

Kataboi and Buluk transverse fault zones (Figure 10d), and responsible for the structural segmentation of the Turkana rift, as a whole (W. Vétel and B. Le Gall, Dynamic of continental extension in magmatic rifts: The study case of the Turkana Rift since the last $45 \mathrm{Ma}$ (northern Kenya), submitted to Journal of the Geological Society of London, 2005; hereinafter referred to as Vétel and Le Gall, submitted manuscript, 2005). The possible contributing role of the NTFZ with respect to the inverted deformation in part of the Turkana rift is discussed in the kinematic model below.

\subsubsection{Kinematic Hypotheses}

[36] Applying a kinematic model to any deformed areas requires the accurate characterization of the principal strain axes and/or those of the corresponding applied stress field $\left(\sigma_{1} / \sigma_{2} / \sigma_{3}\right)$ [e.g., see Ziegler and Cloetingh, 2004. The data and assumptions discussed below about the Turkana rift lead us to establish a three-stage evolutionary model dominated by rapid changes of the stress field conditions during recent periods $(<5 \mathrm{Ma})$ (Figure 11). In contrast, the long-lived (33-5 Ma) earlier rifting stage is inferred to have occurred under a constant extensional stress field (Figure 11a) with a $\sim \mathrm{N} 90^{\circ} \mathrm{E}$ directed horizontal extension $\left(\sigma_{3}\right)$ only deduced from the $\sim \mathrm{NS}$ orientation of the master syndepositional rift fault network (Lokichar, Kerio) [Morley et al., 1992]. Reliable data are not available to constrain the paleostress field of the Turkana rifted zone during the onset of basin inversion $(<5 \mathrm{Ma})$. Field measurements of recent fault planes are too few and the kinematics of seismically imaged faults is 

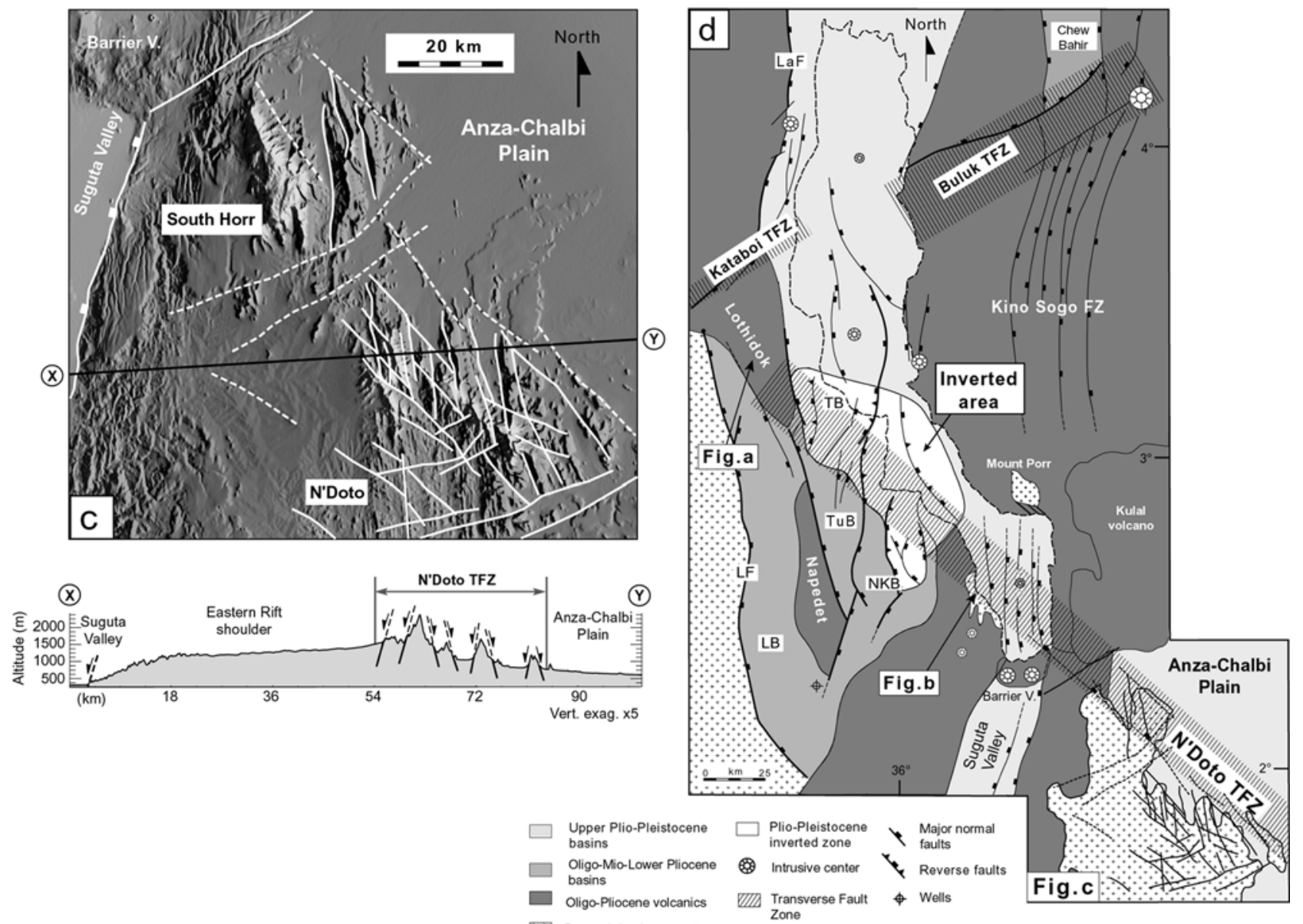

Figure 10. (continued)

poorly known. Despite these limitations, kinematic hypotheses are attempted, based on the 2D-mapped arrangement of extensional and inverted fault networks (Figures $11 \mathrm{~b}$ and $11 \mathrm{c})$, as well as on the recent rift kinematics known elsewhere in the EARS, and compared with experimental models.

[37] Comparing the two fault maps of stages 5-3.7 Ma and 3.7 Ma-Present shows the preferential development of young anomalous rift structures, involving both extensional and inverted deformation, above the long-lived NTFZ discontinuity. These characteristics suggest similarity with models of deformed cover sequences on top of a basement fault reactivated in a dominantly strike-slip mode [Richard et al., 1989, 1995; Higgins and Harris, 1997]. According to these experiments, the trace of en echelon extensional fractures makes an angle of $45^{\circ}$ in plan view to the shear direction [Tchalenko, 1970; Sylvester, 1984]. Similar angular relationships are observed in the present case study between the (initially normal) $\mathrm{N} 20^{\circ} \mathrm{E}$ fault network (assimilated to T-type fractures) and the $\mathrm{N} 140 / 160^{\circ} \mathrm{E}$ orientation of the NTFZ, hence considered as a possible (40 km wide) dextral shear zone. In such a dominant strike-slip fault regime, the horizontal axis of shortening $\left(\sigma_{1}\right)$ should be oriented $\mathrm{N} 20^{\circ} \mathrm{E}$, parallel to the tensional fractures, while the corresponding extension direction $\left(\sigma_{3}\right)$ should be $\mathrm{N} 110^{\circ} \mathrm{E}$ (Figure 11b). From these assumptions, it is therefore suggested that major kinematic changes occurred in the Early Pliocene, marked by the permutation of the principal stress axes $\sigma_{1} / \sigma_{2}$ and the transition from normal fault extension to strike-slip regime. The new stress field favored lateral fault displacement along suitably oriented structures such as the NTFZ which is likely to have undergone dextral reactivation (Figure 11b). Strike-slip tectonics is dominated by initiation of extensional features (T-type fractures) within the shear zone, hence indicating, at first approximation, compressional and extensional axes oriented respectively $\mathrm{N} 20^{\circ} \mathrm{E}$ and $\mathrm{N} 110^{\circ} \mathrm{E}$. A slight $\left(20^{\circ}\right)$ clockwise rotation of extension, from $\mathrm{N} 90^{\circ} \mathrm{E}$ to $\mathrm{N} 110^{\circ} \mathrm{E}$, is thus believed to have also occurred during stress permutation (Figures 11a and 11b). Inversion tectonics developed later under changing stress field conditions dominated by a $\mathrm{N} 130^{\circ} \mathrm{E}$ directed extension, as deduced from the $\mathrm{N} 40^{\circ} \mathrm{E}$ alignment of recent fissure-style volcanic cones throughout the $<1$ Myr old Hurri, Asie and Marsabit shied volcanoes [Key and Watkins, 1988], in the Anza-Chalbi desert to the east of the study area (Figure 11c). A similar switch of the extension direction to NW-SE during Upper Pliocene is also proposed by other authors for other parts of the EARS [Strecker et al., 1990; Bosworth et al., 


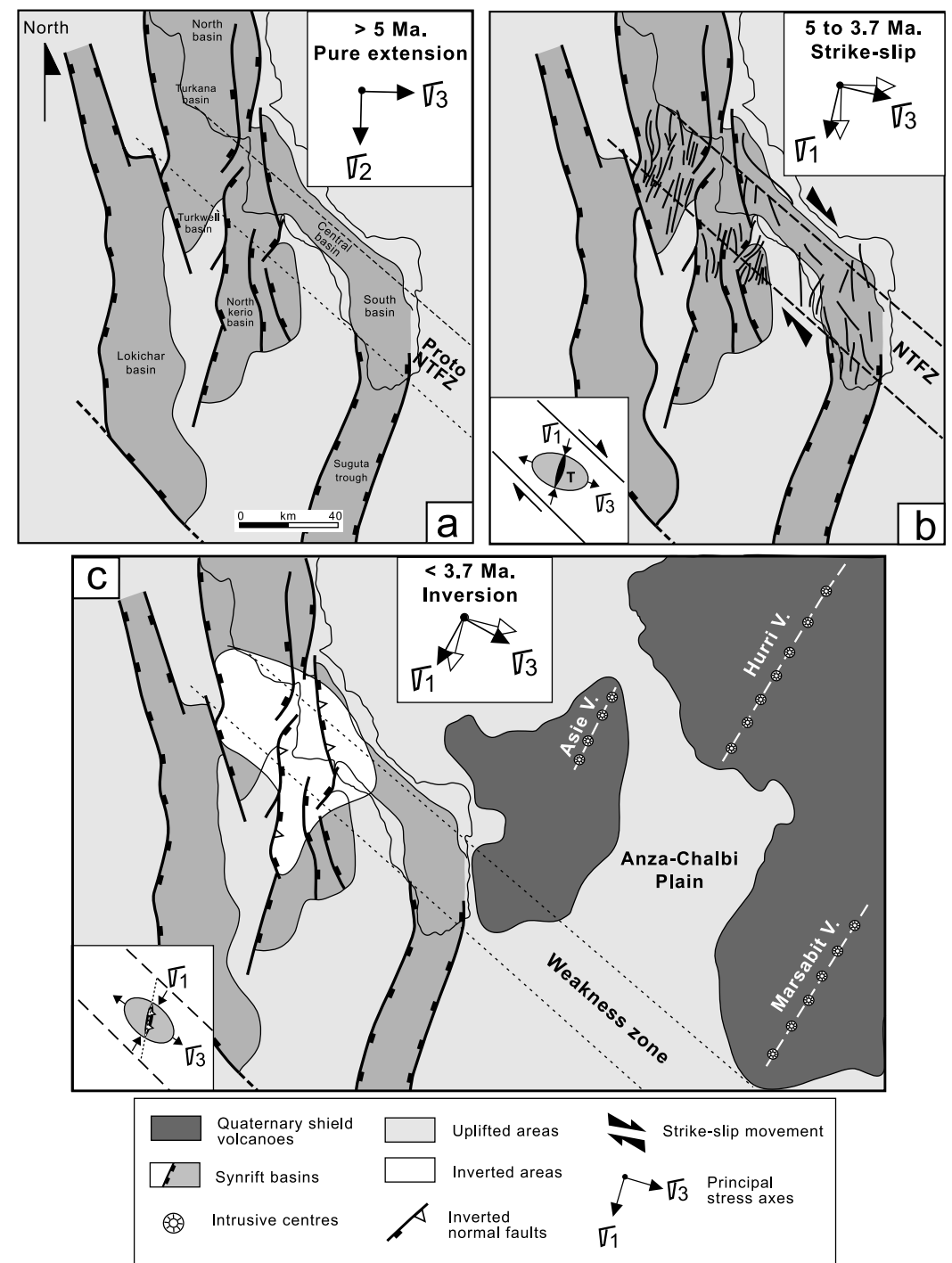

Figure 11. Three-stage kinematic model for the Turkana rift from Miocene times onward. For each evolutionary stage, the trace of modern Lake Turkana is drawn as a geographical reference. (a) Major basin development during Miocene times under pure EW extensional regime. (b) First increment of strike-slip (dextral) reactivation of the N'Doto transverse basement fault zone (NTFZ) as the result of permutation of stress axes $\left(\sigma_{1}\right.$ and $\left.\sigma_{2}\right)$ and the clockwise rotation $\left(\sim 20^{\circ}\right)$ of horizontal principal stress axes. The dense tensional fault pattern in the north Kerio, Turkwell, and Turkana basins might have formed as " $T$ " Riedel-type structures within a transverse corridor controlled at depth by the reactivated NTFZ. (c) Basin inversion stage illustrating the rejuvenation of earlier extensional faults under an oblique shortening regime. The $\sim \mathrm{N} 130^{\circ} \mathrm{E}$ direction of the corresponding extension $\left(\sigma_{3}\right)$ is deduced from aligned Quaternary intrusive centers. At this stage, the NTFZ is no longer dextrally reactivated.

1992; Delvaux et al., 1992; Bosworth and Strecker, 1997]. The corresponding shortening direction was thus nearly $\mathrm{N} 40^{\circ} \mathrm{E}$, i.e., slightly oblique to the $\mathrm{NS}$ and $\mathrm{N} 20^{\circ} \mathrm{E}$ trends of earlier tensional fault/fracture networks that are likely to have been reactivated as oblique reverse structures. One consequence of this recent stress axes rotation $\left(\sim 20^{\circ}\right.$ in a still clockwise sense) is that the direction of the inferred regional shortening axis $\left(\sim \mathrm{N} 40^{\circ} \mathrm{E}\right)$ is at high angle (nearly $80^{\circ}$ ) to the NTFZ, hence preventing any further strike-slip reactivation of the $\mathrm{N} 140^{\circ} \mathrm{E}$ fault system (Figure 11c).

[38] As mentioned above about the spatial distribution of inverted deformation, rift-parallel fault structures (NS to $\mathrm{N} 20^{\circ} \mathrm{E}$ ) lying outside the NTFZ with a similar reactivation potential (Lokichar and Lapurr faults, as well as the Kino Sogo and Suguta fault systems drawn on Figure 10d) show no evidence of inversion. It thus appears that strain preferentially concentrated within the 
NTFZ, probably as the result of a decreasing crustal strength caused by steep mechanically weak planes in the basement. The key role of prerift anisotropies on the existence of such crustal weakness zones (analogue to the NTFZ) in rift systems is commonly reported elsewhere [Ziegler et al., 1995; Ziegler and Cloetingh, 2004].

[39] We therefore come to the conclusion that basin inversion in the Turkana rift mainly results from the combined effects of stress field changes (permutation and, to a lesser extent, clockwise rotation of principal stress axes $\left.\sigma_{1} / \sigma_{2}\right)$, and the mechanical behavior of a long-lived crustalscale weakness zone oblique to the rift axis.

\section{Conclusions}

[40] Three kinds of folded structures are present in the Turkana rift, one kind arose during extension, and the other two are associated with inversion of extensional structures. Around Lake Turkana, folds are found adjacent to igneous intrusion complexes, and appear to have originated as a result of intrusion emplacement during the Pliocene. The third kind of inverted structures is the main focus of this study. The inversion structures occurred later than $3.7 \mathrm{Ma}$ and have a patchy distribution in five main areas, predominantly in the eastern parts of the onshore rifts, extending into Lake Turkana. The region affected by inversion is confined to an elongate transverse corridor trending $\mathrm{N} 160^{\circ} \mathrm{E}$, with dimensions about $40 \mathrm{~km} \times 100 \mathrm{~km}$, and referred to as the N'Doto transverse fault zone (NTFZ). The NTFZ appears to be related to basement discontinuities oblique to the rift that have been described in a related study (Vétel and Le Gall, submitted manuscript, 2004). It is proposed in this study that partial inversion of the Turkana rift basins results from two major changes in the stress regime during Pliocene times. The first kinematic stage is dominated by stress axes permutation $\sigma_{1} / \sigma_{2}$ that leads to the transition from an extensional regime, where the least principal stress was oriented $\mathrm{N} 90^{\circ} \mathrm{E}$, to a transpressional wrench regime where extension was furthermore slightly rotated $\left(\sim 20^{\circ}\right)$ to $\mathrm{N} 110^{\circ} \mathrm{E}$. The tensional faults formed within the dextral shear zone (NTFZ) are subsequently inverted, in association with strata folding, as the result of the ongoing clockwise rotation $\left(\sim 20^{\circ}\right)$ of the shortening direction $\left(\mathrm{N} 40^{\circ} \mathrm{E}\right)$ which is thus oblique to the $\mathrm{N} 20^{\circ} \mathrm{E}$ extensional structures. Similar conclusions about causal links between inversion tectonics and permutation of stress axes have been envisaged elsewhere [Illies and Greene, 1978], and more locally for the recent kinematic evolution of the Malawi rift, in the southern part of the EARS [Ring et al., 1992].

[41] The suggestions made above about the recent kinematic framework of the Turkana rifted zone are tentative and should be further properly evaluated with an integration of additional field data dealing with recent fault motion.

[42] Acknowledgments. Fieldwork was supported by the ECLIPSE (Environnements et Climats du Passé) Program INSU-CNRS (Dir. H. Roche). Authors thank the National Oil Corporation of Kenya for providing the seismic data set and for field logistics. They are also grateful to the two referees for their helpful comments and more particularly to Damien Delvaux for his thorough review which was very useful for improving the paper. This publication is contribution 935 of the IUEM, European Institute for Marine Studies (Brest, France).

\section{References}

Arthaud, F., P. Choukroune, and B. Robineau (1980), Tectonique, microtectonique et évolution structurale du golfe de Tadjoura et du Sud de la dépression Afar (Rép. De Djibouti), Bull. Soc. Geol. Fr., 22(6), 901-908

Bosworth, W. (1992), Mesozoic and early Tertiary rift tectonics in East Africa, Tectonophysics, 209, 115 137.

Bosworth, W., and A. Maurin (1993), Structure, geochronology and tectonic significance of the northern Suguta Valley (Gregory Rift), Kenya, J. Geol. Soc. London, 150, 751-762.

Bosworth, W., and C. K. Morley (1994), Structural and stratigraphic evolution of the Anza rift, Kenya, Tectonophysics, 236, $93-115$.

Bosworth, W., and M. R. Strecker (1997), Stress field changes in the Afro-Arabian rift system during the Miocene to Recent period, Tectonophysics, 278, $47-62$.

Bosworth, W., M. R. Strecker, and P. M. Blisniuk (1992), Integration of East African paleostress and present-day stress data: Implications for continental stress field dynamics, J. Geophys. Res., 97(B8), $11,851-11,865$.

Boulet, S. (2003), Stratigraphie sismique et séquentielle de dépots fluvio-lacustres en contexte de rift: Application au bassin oligo-miocène de Lokichar, région du lac Turkana, Rift Est-Africain, 47 pp., DEA master report, Univ. of Brest., France.

Brekke, H., and F. Riis (1987), Tectonics and basin evolution of the Norwegian shelf between $62^{\circ} \mathrm{N}$ and $72^{\circ} \mathrm{N}$, Nor. Geol. Tisskr., 67, 295-322.
Brun, J.-P., and T. Nalpas (1996), Graben inversion in nature and experiments, Tectonics, 15, $677-$ 687.

Coward, M. P. (1996), Balancing sections through inverted basins, in Modern Development in Structural Interpretation, Validation and Modelling, edited by, P. G. Buchanan and D. A. Nieuwland, Geol. Soc. Spec. Publ., 99, 51-77.

Curewitz, D., and J. A. Karson (1998), Geological consequences of dike intrusion at mid-ocean ridge spreading centers, in Faulting and Magmatism at Mid-Ocean Ridges, Geophys. Monogr. Ser., vol. 106, edited by W. R. Buck et al., pp. $117-$ 136, AGU, Washington, D. C.

Delvaux, D., K. Levi, R. Kajara, and J. Sarota (1992), Cenozoic paleostress and kinematic evolution of the Rukwa-north Malawi rift valley (East African rift system), Bull. Cent. Rech. Explor. Prod. Elf Aquitaine, 16(2), 383-406.

Dindi, E. W. (1994), Crustal structure of the Anza graben from gravity and magnetic investigations, $\mathrm{Tec}$ tonophysics, 236, 359-371.

Doré, A. G., and E. R. Lundin (1996), Cenozoic compressional structures on the NE Atlantic margin: Nature, origin and potential significance for hydrocarbon exploration, Pet. Geosci., 2, 299-311.

Doré, A. G., E. R. Lundin, C. Fichler, and O. Olesen (1999), Patterns of basement structure and reactivation along the NE Atlantic margin, J. Geol. Soc. London, 154, 85-92.

Dunkelman, T. J., B. R. Rosendahl, and J. A. Karson (1989), Structure and stratigraphy of the Turkana rift from seismic reflection data, J. Afr. Earth Sci., $8,489-510$.

Ebinger, C. J., and A. Ibrahim (1994), Multiple episodes of rifting in central and East Africa: A reevaluation of gravity data, Geol. Rundsch., 83, $689-702$.

Ebinger, C. J., T. Yemane, D. J. Harding, S. Tesfaye, S. Kelley, and D. Rex (2000), Rift deflection, migration and propagation: Linkage of the Ethiopian and Eastern rifts, Africa, Geol. Soc. Am. Bull., 112, $163-176$.

Ferguson, A. J., and B. J. Harbott (1982), Geographical, physical and chemical aspects of Lake Turkana, in Lake Turkana: A Report on the Findings of the Lake Turkana Project 1972-1975, edited by A. J. Hopson, pp. 1-107, Overseas Dev. Admin., London.

Foster, D. A., and A. J. Gleadow (1992), The morphotectonic evolution of rift-margin mountains in central Kenya: Constraints from apatite fission-track thermochronology, Earth Planet. Sci. Lett., 113, $157-171$.

Gaulier, J. M., and P. Huchon (1991), Tectonic evolution of the Afar triple junction, Bull. Soc. Geol. Fr, 162(3), 451-464.

Gibbs, A. D. (1984), Structural evolution of extensional basin margins, J. Geol. Soc. London, 141, 609-620.

Gillcrist, R., M. P. Coward, and J. L. Mugnier (1987), Structural inversion, examples from the Alpine foreland and the French Alps, Geodin. Acta, 1, 5-34.

Haileab, B., F. H. Brown, I. McDougall, and P. N. Gathogo (2004), Gombe Group basalts and initia- 
tion of Pliocene deposition in the Turkana depression, northern Kenya and southern Ethiopia, Geol. Mag., 141(1), 41-53.

Harding, T. P. (1983), Seismic characteristics and identification of negative flower structures, positive flower structures and positive structural inversion, AAPG Bull., 69, 582-600.

Hendrie, D. B., N. J. Kusznir, C. K. Morley, and C. J. Ebinger (1994), Cenozoic extension in northern Kenya: A quantitative model of rift basin development in the Turkana region, Tectonophysics, 236, $409-438$

Higgins, R. I., and L. B. Harris (1997), The effect of cover composition on extensional faulting above reactivated basement faults: Result from analogue modeling, J. Struct. Geol, 19(1), 89-98.

Hill, K. C., and G. T. Cooper (1996), A strategy for palinspatic restoration of inverted basins: Thermal and structural analyses in SE Australia, in Modern Development in Structural Interpretation, Validation and Modelling, edited by P. G. Buchanan and D. A Nieuwland, Geol. Soc. Spec. Publ., 99, 99-115.

Illies, J. H., and G. Greene (1978), Rhinegraben and the Alpine system, Geol. Soc. Am. Bull., 89, 770-782.

Key, R. M., and R. T. Watkins (1988), Geology of the Sabarei area, Rep. 111, 57 pp., Minist. of Environ. and Nat. Resour., Mines and Geol. Dep., Minist. of Kenya, Nairobi.

Mohr, P. A., and C. A. Wood (1976), Volcano spacing and lithospheric attenuation in the Eastern Rift of Africa, Earth Planet. Sci. Lett., 33, 126-140.

Morley, C. K. (1999), Aspect of transfer zone geometry and evolution in East African rifts, in Geoscience of Rift Systems: Evolution of East Africa, edited by C. K. Morley, AAPG Stud. Geol., 44, 161-171.

Morley, C. K., W. A. Wescott, D. M. Stone, R. M. Harper, S. T. Wigger, and F. M. Karanja (1992), Tectonic evolution of the northern Kenyan Rift, J. Geol. Soc. London, 149, 333-348.

Morley, C. K., R. M. Harper, and S. T. Wigge (1999a), Tectonic Inversion in East Africa, in Geoscience of Rift Systems: Evolution of East Africa, edited by C. K. Morley, AAPG Stud. Geol., 44, 193-210.

Morley, C. K., W. A. Wescott, R. M. Harper, S. T. Wigger, R. A. Day, and F. M. Karanja (1999b), Geology and geophysics of the western Turkana basins, Kenya, in Geoscience of Rift Systems: Evolution of East Africa, edited by C. K. Morley, AAPG Stud. Geol., 44, 19-54.
Morley, C. K., R. A. Day, R. Lauck, R. Bosher, D. M Stone, S. T. Wigger, W. A. Wescott, D. Haun, N. Bassett, and W. Bosworth (1999c), Geology and geophysics of the Anza graben, in Geoscience of Rift Systems: Evolution of East Africa, edited by C. K. Morley, AAPG Stud. Geol., 44, 67-90.

National Oil Corporation of Kenya (1992), Shell report, 40 pp., Well Resume Eliye Springs-1, Nairobi.

Opheim, J. O., and A. Gudmundsson (1989), Formation and geometry of fractures, and related volcanism, of the Krafla fissure swarm, northeast Iceland, Geol. Soc. Am. Bull., 101, 1608-1622.

Price, S., J. Brodie, A. Witham, and R. Kent (1997) Mid-Tertiary rifting and magmatism in the Traill $\mathrm{O}$ region, east Greenland, J. Geol. Soc., London, 154 , $419-434$.

Reeves, C. V., F. M. Karanja, and I. N. McLeod (1987), Geophysical evidence for a failed Jurassic rift and triple junction in Kenya, Earth Planet. Sci. Lett. $81,299-311$

Richard, P. D., J. F. Ballard, B. Colletta, and P. R. Cobbold (1989), Fault initiation and development above a basement strike-slip fault: Analogue modeling and tomography, C. R. Acad. Sci., 309(11) 2111-2118.

Richard, P. D., M. A. Naylor, and A. Koopman (1995), Experimental models of strike-slip tectonics, Pet Geosci., 1, 71-80.

Ring, U. (1994), The influence of preexisting structure on the evolution of the Cenozoic Malawi rift (East African rift system), Tectonics, 13, 313-326.

Ring, U., C. Betzler, and D. Delvaux (1992), Normal versus strike-slip faulting during rift development in East Africa: The Malawi Rift, Geology, 20, 1015 1018.

Rosendahl, B. R. (1987), Architecture of the continental rifts with special reference to East Africa, Annu. Rev. Earth Planet. Sci., 15, 445-503.

Rubin, A. M., and D. D. Pollard (1988), Dike-induced faulting in rift zones of Iceland and Afar, Geology, 16, 413-417.

Schull, T. J. (1988), Rift basins of interior Sudan: Petroleum exploration and discovery, Am. Assoc. Petrol. Geol. Bull., 72, 1128-1162.

Spetch, T. D., and B. R. Rosendahl (1989), Architecture of the Lake Malawi rift, East Africa, J. Afr. Earth Sci., 8, 393-413.

Strecker, M. R., P. M. Blisniuk, and G. H. Eisbacher (1990), Rotation of extension direction in the central Kenya Rift, Geology, 18, 299-302.
Sylvester, A. G. (Compiler) (1984), Wrench fault tectonics, AAPG Rep. Ser., 28, 374 pp.

Tchalenko, J. S. (1970), Similarities between shear zones of different magnitudes, Geol. Soc. Am. Bull., $81,1625-1640$

Vétel, W., B. Le Gall, and T. C. Johnson (2004), Active tectonics in the Turkana Rift (north Kenya): An integrated approach from drainage network, satellite imagery and reflection seismic analyses, Basin Res., 16(2), 165-181.

Villemin, T., F. Bergerat, J. Angelier, and C. Lacasse (1994), Brittle deformation and fracture patterns on oceanic rift shoulders: The Esja peninsula, SW Iceland, J. Struct. Geol., 16(12), 1641-1654.

Winn, R. D., J. C. Steinmetz, and W. L. Kerekgyarto (1993), Stratigraphy and rifting history of the Mesozoic-Cenozoic Anza Rift, Kenya, AAPG Bull., $77,1989-2005$

Ziegler, P. A. (1987), Compressional intra-plate tectonics in the Alpine foreland, Tectonophysics, 137, $389-420$

Ziegler, P. A. (1988), Evolution of the Arctic-North Atlantic and the Western Tethys, AAPG Mem., 43 , $198 \mathrm{pp}$

Ziegler, P. A. (1989), Geodynamic model for Alpine intra-plate compressional deformation in western and central Europe, in Inversion Tectonics, edited by M. A. Cooper and G. D. Williams, Geol. Soc Spec. Publ., 44, 63-85.

Ziegler, P. A., and S. Cloetingh (2004), Dynamic processes controlling evolution of rifted basins, Earth Sci. Rev., 64, 1-50.

Ziegler, P. A., S. Cloetingh, and J. D. Van Wees (1995), Dynamics of intraplate compressional deformation: The Alpine foreland and other examples, Tectonophysics, 252, 7-59.

B. Le Gall and W. Vétel, UMR 6538 "Domaines Océaniques," Institut Universitaire Européen de la Mer/CNRS-UBO, Place Nicolas Copernic, F-29280 Plouzané, France. (blegall@univ-brest.fr; wvetel@ univ-brest.fr)

C. K. Morley, Department of Petroleum Geoscience, Universiti Brunei Darussalam, Jalan Tungku Link, Gadong BE1410, Negara Brunei Darussalam. (chrissmorley@yahoo.co.uk) 